\title{
Microbial community and geochemical analyses of trans-trench sediments for understanding the roles of hadal environments
}

\author{
Satoshi Hiraoka $\mathbb{1}^{1} \cdot$ Miho Hirai $^{2} \cdot$ Yohei Matsui $\mathbb{D}^{3,4,9} \cdot$ Akiko Makabe $^{2} \cdot$ Hiroaki Minegishi $^{2,10} \cdot$ Miwako Tsuda $^{2} \cdot$ \\ Juliarni $^{3}$ - Eugenio Rastelli ${ }^{5}$. Roberto Danovaro ${ }^{5,6}$ - Cinzia Corinaldesi ${ }^{7} \cdot$ Tomo Kitahashi $^{8} \cdot$ Eiji Tasumi $^{2}$.

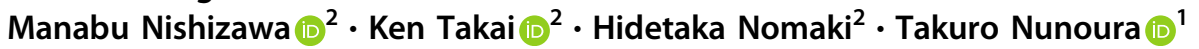

Received: 9 August 2019 / Revised: 20 November 2019 / Accepted: 28 November 2019 / Published online: 11 December 2019

(c) The Author(s) 2019. This article is published with open access

\begin{abstract}
Hadal trench bottom ( $>6000 \mathrm{~m}$ below sea level) sediments harbor higher microbial cell abundance compared with adjacent abyssal plain sediments. This is supported by the accumulation of sedimentary organic matter (OM), facilitated by trench topography. However, the distribution of benthic microbes in different trench systems has not been well explored yet. Here, we carried out small subunit ribosomal RNA gene tag sequencing for 92 sediment subsamples of seven abyssal and seven hadal sediment cores collected from three trench regions in the northwest Pacific Ocean: the Japan, Izu-Ogasawara, and Mariana Trenches. Tag-sequencing analyses showed specific distribution patterns of several phyla associated with oxygen and nitrate. The community structure was distinct between abyssal and hadal sediments, following geographic locations and factors represented by sediment depth. Co-occurrence network revealed six potential prokaryotic consortia that covaried across regions. Our results further support that the OM cycle is driven by hadal currents and/or rapid burial shapes microbial community structures at trench bottom sites, in addition to vertical deposition from the surface ocean. Our trans-trench analysis highlights intra- and inter-trench distributions of microbial assemblages and geochemistry in surface seafloor sediments, providing novel insights into ultradeep-sea microbial ecology, one of the last frontiers on our planet.
\end{abstract}

Supplementary information The online version of this article (https:// doi.org/10.1038/s41396-019-0564-z) contains supplementary material, which is available to authorized users.

Satoshi Hiraoka hiraokas@jamstec.go.jp

$\triangle$ Takuro Nunoura takuron@jamstec.go.jp

1 Research Center for Bioscience and Nanoscience (CeBN), Japan Agency for Marine-Earth Science and Technology (JAMSTEC), 2-15 Natsushima-cho, Yokosuka 237-0061 Kanagawa, Japan

2 Institute for Extra-cutting-edge Science and Technology Avantgarde Research (X-star), Japan Agency for Marine-Earth Science and Technology (JAMSTEC), 2-15 Natsushima-cho, Yokosuka 237-0061 Kanagawa, Japan

3 Project Team for Development of New-generation Research Protocol for Submarine Resources, Japan Agency for MarineEarth Science and Technology (JAMSTEC), 2-15 Natsushimacho, Yokosuka 237-0061 Kanagawa, Japan

4 Research and Development Center for Submarine Resources, Japan Agency for Marine-Earth Science and Technology

\section{Introduction}

The abyssal plain extends from the continental slope to the rim of deep trenches (3000-6000 $\mathrm{m}$ below sea level [mbsl])

(JAMSTEC), 2-15 Natsushima-cho, Yokosuka 237-0061

Kanagawa, Japan

5 Stazione Zoologica Anton Dohrn, Villa Comunale, Naples 80121, Italy

6 Department of Life and Environmental Sciences, Polytechnic University of Marche, Ancona 60131, Italy

7 Department of Materials, Environmental Sciences and Urban Planning, Polytechnic University of Marche, Ancona 60131, Italy

8 Marine Biodiversity and Environmental Assessment Research Center (BioEnv), Japan Agency for Marine-Earth Science and Technology (JAMSTEC), 2-15 Natsushima-cho, Yokosuka 237-0061 Kanagawa, Japan

9 Present address: Atmosphere and Ocean Research Institute, The University of Tokyo, 5-1-5 Kashiwanoha, Kashiwa, Chiba 2778564, Japan

10 Present address: Faculty of Science and Engineering, Toyo University, 2100 Kujirai, Kawagoe 350-8585 Saitama, Japan 
and covers $85 \%$ of the global seafloor area, while the hadal zone (>6000 mbsl) comprises $1-2 \%$ of it $[1,2]$. In general, abyssal water and sediments are usually oligotrophic, and physical and chemical conditions (e.g., salinity, temperature, dissolved oxygen, and nutrient concentrations) in hadal water are similar to the overlying abyssal water despite the higher hydrostatic pressure [1-3]. However, cell abundance and microbial carbon turnover rates are significantly higher at hadal trench bottom compared with abyssal plain sediment below the surface layer, while those in outermost surface layer are sometimes comparable between hadal and abyssal sites [4]. This could be hypothesized to be attributed to factors apart from the vertical downward flux of sinking organic matter (OM) from the ocean surface and hydrostatic pressure.

Hadal zones are generally located in oceanic trenches that are formed along plate boundaries by the movement of oceanic plates, and thus experience episodic and/or regular landslides [5, 6]. These landslides cause downward transportation of surface sediments along with relatively fresh OM via the funnel effect of trench geomorphology [7-11]. Moreover, higher sedimentation rates and concentrations of subseafloor organic compounds in hadal trench bottom sediments compared with neighboring abyssal plain sediments have been reported in multiple trench regions under oligotrophic and eutrophic oceans [4, 11-14]. Therefore, the labile organic carbon deposition in hadal zone supported by the high sedimentation is considered to facilitate establishment of distinct faunal and prokaryotic community observed at global scales [15-19]. Recently, the influence of physicochemical features on hadal biospheres were reported for microbial communities in the Mariana and Kermadec Trench regions [20, 21], where under oligotrophic and relatively eutrophic (intermediate) ocean, respectively $[22,23]$; the pioneering studies reported microbial biodiversity in hadal trench bottom, trench slope, and adjusted abyssal plain sediments using culture-independent highthroughput sequencing techniques, and consequently demonstrated the structural similarity among each abyssal and hadal site. However, relations between geochemistry and microbial composition in hadal trench bottom and adjacent abyssal sediments have been still uninvestigated.

Here, we evaluated prokaryotic community structure in 92 sediment subsamples of 14 sediment cores collected from four hadal trench bottom and seven adjacent abyssal plain sites located in three trenches in the northwest Pacific Ocean; the Japan, Izu-Ogasawara (Izu-Bonin), and Mariana Trenches (Fig. 1 and Table S1). The Japan and Mariana Trenches lie under eutrophic and oligotrophic oceans, respectively, while the primary productivity of the ocean above the Izu-Ogasawara Trench presents intermediate features. We performed geochemical analyses of the sediments and culture-independent microbial analyses including direct cell count, quantitative polymerase chain reaction (qPCR), and tag sequencing for small subunit ribosomal RNA (SSU rRNA) gene, to investigate intra- and intertrench diversities of prokaryotic communities and potential metabolic interactions using co-occurrence networks. Our analyses illuminated the distinctive prokaryotic assemblages that spread through the trenches in each of abyssal and hadal zones, providing new insights into the microbial ecology in deep ocean, where one of the least understood aquatic habitats.

\section{Materials and methods}

\section{Sediment samplings}

Sediment cores were collected over five cruises by Japan Agency for Marine-Earth Science and Technology (JAMSTEC); Research Vessel (R/V) Kairei KR11-11 (December 2011) and KR15-01 (March 2015) cruises and R/V Yokosuka YK11-06 (September 2011) cruise for the IzuOgasawara Trench, R/V Kairei KR12-19 (December 2012) cruise for the Japan Trench, and R/V Kairei KR14-01 cruise (January 2014) for the Mariana Trench (Fig. 1 and Table S1). The water depths ranged from 4700 to 10,902 mbsl. Among the 11 sites, four were located on the hadal trench bottom ("hadal sites"), while the other seven were located on the adjacent abyssal plain ("abyssal sites").

Sediment cores were obtained by a gravity corer of the remotely operated vehicle (ROV) "ABISMO" [24] during KR11-11 and KR15-01 cruises, a free fall $11 \mathrm{~K}$ lander system [25] during KR11-11, KR12-19, and KR15-01 cruises, a multiple corer system during KR14-01 cruise, and push corers of human occupied vehicle (HOV) "Shinkai 6500" during YK11-06 cruise. In each sampling operation, a Conductivity, Temperature, and Depth sensor SBE-19 or SBE-49 (Sea-Bird Electronics, Bellevue, WA, USA) was used. Among the sampling operations, two operations were conducted for sites IO1 and IOC in the Izu-Ogasawara Trench (station pairs IO1-1 and IO1-2, and IOC-1 and IOC2 , respectively) and site MC in the Mariana Trench (MC-1 and MC-2). Sediment core lengths taken by the push corer, multiple corer, and $11 \mathrm{~K}$ lander system ranged from 25 to 50 $\mathrm{cm}$, while those collected from IOB and IOC-1 stations using the gravity corer were $\sim 120-150 \mathrm{~cm}$. Note that sediment-water interface of the sediment cores taken by the gravity corer might be more disturbed by sampling operations compared with the other coring systems.

Collected sediment cores were immediately subsampled onboard at 2- to 10-cm-depth intervals for geochemical and microbiology analyses. Porewater was extracted by centrifugation at $2600 \times g$ for $10 \mathrm{~min}$, and then supernatant (seawater) was filtered using a $0.2-\mu \mathrm{m}$ syringe cartridge 

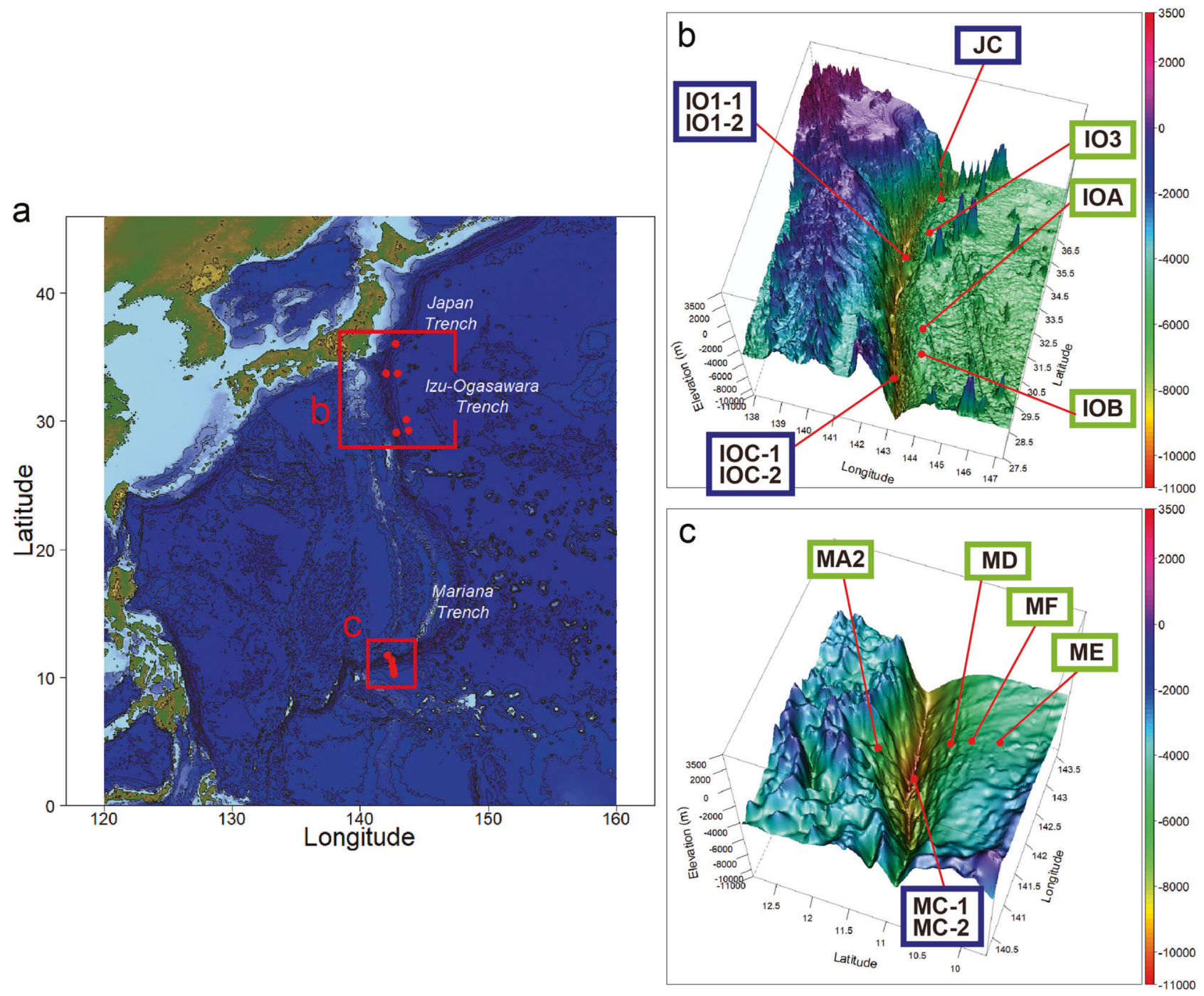

Fig. 1 Maps of the sampling stations of sediment cores and their geographic locations. Plane (a) and three-dimensional (b, c) maps are shown. Stations with green and blue rectangles represent abyssal and

filter. Subsamples were stored at -80 and $-20^{\circ} \mathrm{C}$ for molecular and geochemical analyses, respectively. Sediment samples for direct cell counting were fixed with or without $5 \mathrm{~mL}$ formaldehyde solution (final concentration $2 \% \mathrm{w} / \mathrm{v}$ in PBS buffer) for $1 \mathrm{~h}$ at room temperature onboard and stored at $-80^{\circ} \mathrm{C}$.

\section{Geochemical analyses}

Dissolved oxygen $\left(\mathrm{O}_{2}\right)$ concentrations in the sediment cores were measured onboard immediately after core recovery using a planar optode oxygen sensor Fibox 3 (PreSens, Regensburg, Germany). For the gravity core samples, small $(\sim 3 \mathrm{~mm})$ holes were opened along the side of the core tube at $2-5 \mathrm{~cm}$ depth intervals, and the sensor was inserted into the sediments. For sediment cores collected by the push corer, multiple corer, and $11 \mathrm{~K}$ lander system, the sensor spots were hadal sites, respectively. The dashed line of JC station indicates that the station is located behind the seamount.

attached to the inside of the transparent polycarbonate core liner tube and oxygen concentrations were measured from the outside. The sensors were calibrated with air-saturated and oxygen-free seawater before measurements. Porewater nutrient concentrations $\left(\mathrm{NO}_{3}^{-}, \mathrm{NO}_{2}^{-}, \mathrm{PO}_{4}\right.$, and $\left.\mathrm{NH}_{4}^{+}\right)$were analyzed spectrophotometrically using an automated continuous-flow QuAAtro 2-HR analyzer (BL TEC, Osaka, Japan) in an onshore laboratory [26].

Total organic carbon (TOC), total nitrogen (TN), and their $\mathrm{C}$ and $\mathrm{N}$ isotopic compositions were measured by flash combustion with an elemental analyzer Flash EA 1112 series coupled via ConfloIV to an isotope ratio mass spectrometer DELTAplus Advantage (Thermo Fisher Scientific, Waltham, MA, USA) for KR15-01 sediment samples or DELTA V Advantage (Thermo Fisher Scientific) for the other sediment samples. Before measuring, the sediment samples were freeze-dried and acidified with $1 \mathrm{M} \mathrm{HCl}$ to 
remove inorganic carbon. The decalcified sediments were then dried, weighed, and put into precleaned tin cups for flash combustion. The stable isotope ratios are reported as $\delta$ values, in which $\delta=\left(\mathrm{R}^{\mathrm{sam}} / \mathrm{R}^{\text {std }}-1\right) \times 1000$, with $\mathrm{R}$ being the isotope ratios (either ${ }^{13} \mathrm{C} /{ }^{12} \mathrm{C}$ or ${ }^{15} \mathrm{~N} /{ }^{14} \mathrm{~N}$ ) in the sample and standard, respectively. The carbon isotope ratio of TOC was referenced against Vienna Pee Dee Belemnite. The nitrogen isotope ratios of $\mathrm{TN}$ were referenced against atmospheric $\mathrm{N}_{2}$. The analytical precision achieved through repeated analyses of in-house standards was typically better than $0.2 \%$ for both $\delta^{13} \mathrm{C}$ and $\delta^{15} \mathrm{~N}$.

\section{Cell counting}

For determining total cell abundance in sediments collected during KR11-11, KR12-19, and KR14-01 cruises, microbial cells were fixed with sterile $0.2-\mu \mathrm{m}$ prefiltered $3.7 \%$ formaldehyde solution onboard and stored at $-80^{\circ} \mathrm{C}$ until subsequent processes onshore as follows. The samples were centrifuged, washed with $4.5 \mathrm{~mL}$ PBS buffer, and resuspended in a PBS and $100 \%$ ethanol (1:1) mixture. After sonication using a Branson Sonifier 220 (Danbury, CT, USA), samples were diluted, filtered onto $0.2-\mu \mathrm{m}$ polycarbonate filters, and stained using SYBR Green I. Excess stain was removed three times using $3 \mathrm{~mL}$ Milli-Q water, and then filters were mounted onto microscope slides and cells were counted under blue light by epifluorescence microscopy Axioskop 2MOT (Carl Zeiss, Jena, Germany) at $\times 1000$ magnification [27]. For sediments collected from the KR15-01 cruise, frozen samples were suspended in 5 $\mathrm{mL}$ PBS containing $4 \%$ formaldehyde and incubated at $4{ }^{\circ} \mathrm{C}$ for 1-2 h. Samples were then centrifuged, repeatedly washed with PBS, resuspended in $5 \mathrm{~mL}$ PBS and $100 \%$ ethanol $(1: 1)$ mixture, and stored at $-20^{\circ} \mathrm{C}$. Fixed samples were diluted with PBS and sonicated for $20 \mathrm{~s}$ with an ultrasonic homogenizer UH-50 (SMT, Tokyo, Japan). Cells in the aliquant were stained directly using SYBR Green I and counted with an Olympus BX51 fluorescence microscope (Olympus, Tokyo, Japan) at $\times 1500$ magnification [28]. For each filter, at least 400 cells were counted in at least 20 randomly chosen fields.

\section{DNA extraction, qPCR, and sequencing}

Approximately $5 \mathrm{~mL}$ of frozen subsampled sediments from certain cores sections were used for DNA extraction. Environmental DNA was extracted using the PowerSoil DNA Isolation Kit (Qiagen) with a minor modification to increase DNA yield: cells were shaken for $10 \mathrm{~min}$ after incubating at $65^{\circ} \mathrm{C}$ twice.

The abundance of prokaryotic and archaeal SSU rRNA genes was enumerated by qPCR analyses. Primer and probe sequences and PCR conditions are summarized in Table S2
[29, 30]. SSU rRNA gene copy numbers were quantified as averages of duplicates or triplicates for each sediment sample. For the qPCR analyses, 7500 Real-Time PCR System and StepOnePlus Real-Time PCR System (Applied Biosystems, Waltham, MA, USA) were used. For the preparation of qPCR mixtures, qPCR Quick GoldStar Mastermix Plus (Eurogentec, Seraing, Belgium) and Premix Ex Taq (Perfect Real Time) (Takara Bio, Shiga, Japan) were applied. No amplified products were obtained from Milli-Q water as negative control samples in all amplification trials.

For SSU rRNA gene tag sequencing, the V4-V5 region of SSU rRNA gene was amplified from the environmental DNA assemblages using a primer set of U530F and U907R and LA Taq DNA polymerase with GC buffer (Takara Bio) $[31,32]$. Primer sets and PCR conditions are summarized in Table S3. For amplification, Illumina adaptor sequence (ACACTCTTTCCCTACACGACGCTCTTCCGATCT) and Illumina Multiplexing PCR Primer 2.0 sequence (GTGACTGGAGTTCAGACGTGTGCTCTTCCGATCT) were added to the $5^{\prime}$ ends of the primers U530F and U907R, respectively. No amplified products were obtained from Milli-Q water as negative control samples in all amplification trials. The amplicons were mixed with Illumina PhiX control libraries and sequenced by Illumina MiSeq platform (Illumina, San Diego, CA, USA) at JAMSTEC. The letter, serial number, "S," and digits for each sample name represent the sampling site, experimental replication (if conducted), sample type ( $\mathrm{S}$ for sediment), and upper sediment depth of subsampled layer.

\section{Bioinformatics}

For raw sequence data, both ends of reads that contained lowquality bases (Phred quality score $<20$ ) and the adapter sequences were trimmed using TrimGalore (https://github. com/FelixKrueger/TrimGalore) with default settings. The remaining pair-end reads were merged with at least $10 \mathrm{bp}$ overlap using FLASH [33] under default settings. Sequencing reads derived from PhiX genome were removed using Bowtie2 [34] using default settings. Chimeric sequences were filtered out using UCHIME [35] with default settings, and sequences with low complexity or shorter than $100 \mathrm{bp}$ were discarded using PRINSEQ with $-l c \_$threshold 7 setting. All remaining high-quality sequences were clustered with a $97 \%$ identity threshold using VSEARCH [36]. After discarding singletons [37], each cluster was designated as an operational taxonomic unit (OTU). Collector's curve was calculated using RTK [38] with default settings. Nonmetric multidimensional scaling (NMDS) analysis was conducted using Bray-Curtis dissimilarities, and multiresponse permutation procedures (MRPP) test was conducted with 999 permutations and same dissimilarity indices. The taxonomic names of each OTU were systematically assigned using blastn search [39] against 
SILVA database release 132 [40] and retrieving the top hit sequence that showed $e$ values $\leq 1 \mathrm{E}-15$.

A network structure of OTU co-occurrence was visualized using naive statistical metrics with strict cutoff values to consider a valid co-occurrence event. We used OTUs that represent $>0.1 \%$ of the total sequencing pool, and pairwise correlations with $>0.8$ Spearman's correlation coefficient $(\rho)$ with $Q$ values $<0.01$ after Bonferroni correction; networks involved in more than two OTUs were analyzed.

The 16S rRNA gene sequences of Flavobacteriaceae sp. PRS1 and Thaumarchaeota were retrieved from IMG/M [41] and SILVA [40] databases, respectively. The sequences of Thaumarchaeota were systematically reduced in family level via similarity-based clustering with $90 \%$ identity using VSEARCH [36]. A maximum-likelihood tree was constructed using FastTree2 [42] with GTR + CAT option. Phylogenetic clades of Thaumarchaeota were affiliated following past studies [43, 44].

\section{Data deposition}

Amplicon sequence data were deposited into the DDBJ Sequence Read Archive under DRA008185 and DRA008316 (Table S1). All data were registered under BioProject ID PSUB010125.

\section{Results and discussions}

\section{Organic geochemistry}

TOC and TN in the studied sediments ranged from 0.10 to 3.28 and 0.02 to $0.42 \mathrm{wt} \%$, respectively (Figs. S1 and S2). TOC concentrations were in general lower at the abyssal $(0.10-0.55 \mathrm{wt} \%)$ than hadal stations (0.29-3.28 wt\%), although large variations were observed at the hadal stations. At the abyssal sites, TOC concentrations of the outermost layers were $0.42 \pm 0.09 \mathrm{wt} \%(n=7)$, and gradually decreased to $0.22 \pm 0.10 \mathrm{wt} \%$ around $15 \mathrm{~cm}$ below seafloor (cmbsf) (Fig. S1). At the hadal sites TOC concentrations also decreased with sediments depth from $1.39 \pm 0.95 \mathrm{wt} \%$ $(n=6)$ at the outermost layers to $0.95 \pm 0.61 \mathrm{wt} \%$ on average around $15 \mathrm{cmbsf}$. However, variations between the stations were substantially large and decreasing trend is less clear than abyssal sites. These trends are concordant to the previous findings that reported rapid sediment deposition and burial at hadal trench bottom compared with adjacent abyssal plain [4]. Layers with high TOC concentration were found in JC and IO1-2 hadal cores, which may be explained by event deposit (e.g., [9]).

Among the hadal sites, the highest TOC and TN values were detected in the Japan Trench sites (1.63-3.28 and $0.22-0.42 \mathrm{wt} \%$, respectively) and the lowest were observed in the Mariana Trench sites (0.16-0.59 and 0.02-0.08 wt\%, respectively), which differed by an order of magnitude. The $\mathrm{C} / \mathrm{N}$ ratio was concordant with past observations that concentrations of protein, carbohydrate, and lipid were generally higher in the Izu-Ogasawara Trench region compared with the Mariana Trench [45]. The $\delta^{15} \mathrm{~N}$ values of surface sediments may reflect nutrient availability at the ocean surface due to isotopic fractionation during nutrient consumption by phytoplankton [46]; nutrient-rich conditions can lead to lower values $(5.1-5.4 \%$ and $2.4-8.2 \%$ at the Japan and Izu-Ogasawara Trenches, respectively), whereas nutrient-poor conditions cause higher values $(8.9-11.7 \%$ at the Mariana Trench). Thus, the sedimental OM concentrations and traits likely reflect the different geographical settings and productivity of the investigated station. It is generally expected that the organic carbon deposition and subsequent diagenetic process reflects the surface productivity of the overlying ocean. The Japan Trench (station JC) is located under the relatively eutrophic north-western Pacific Ocean, where nutrient-rich Oyashio currents encounter warm Kuroshio currents; In addition, the close distance to Honshu island, Japan, may contribute terrestrial OM to the seafloor $[47,48]$. In contrast, the other stations are located under the oligotrophic Pacific Ocean, far from continents or large islands. In particular, the Mariana Trench region is located near a subtropical gyre known to have one of the lowest surface ocean productivities [49]. Even if definitive conclusions could not be made from the available data, the differences in $\mathrm{C} / \mathrm{N}$ ratios of each site could reflect differences in OM sources as well as stable isotopic signatures.

\section{Porewater chemistry}

We measured concentrations of dissolved oxygen $\left(\mathrm{O}_{2}\right)$ and porewater nutrients $\left(\mathrm{NO}_{3}^{-}, \mathrm{NO}_{2}^{-}, \mathrm{NH}_{4}^{+}\right.$, and $\left.\mathrm{PO}_{4}\right)$ in the obtained cores (Figs. 2 and S3) to study microbial decomposition of sedimentary $\mathrm{OM}$ using oxygen and/or nitrate as electron acceptors [50]. $\mathrm{O}_{2}$ concentrations decreased rapidly with increasing sediment depth in most sediment cores and depleted above $30 \mathrm{cmbsf}$, whilst those of abyssal cores collected from the Mariana Trench showed moderate decreases. The oxygen concentrations and decreasing trends at the Mariana trench region $(\sim 120-180$ and $50-150 \mu \mathrm{M}$ at the abyssal and hadal sites, respectively, in $0-16 \mathrm{cmbsf}$ depth) were generally similar to those previously reported (130-180 and 50-180 $\mu \mathrm{M}$ ) [4]. The $\mathrm{NO}_{3}{ }^{-}$concentrations in outermost layers at all stations except JC were $\sim 35 \mu \mathrm{M}$ and this was concordant with those in seawater at hadal zone in Izu-Ogasawara [8]. In all hadal cores, $\mathrm{NO}_{3}{ }^{-}$concentrations drastically decreased with sediment depth to less than $5 \mu \mathrm{M}$ above $30 \mathrm{cmbsf}$ with a concomitant increase in $\mathrm{NH}_{4}{ }^{+}$concentrations, especially at the Japan and Izu-Ogasawara 


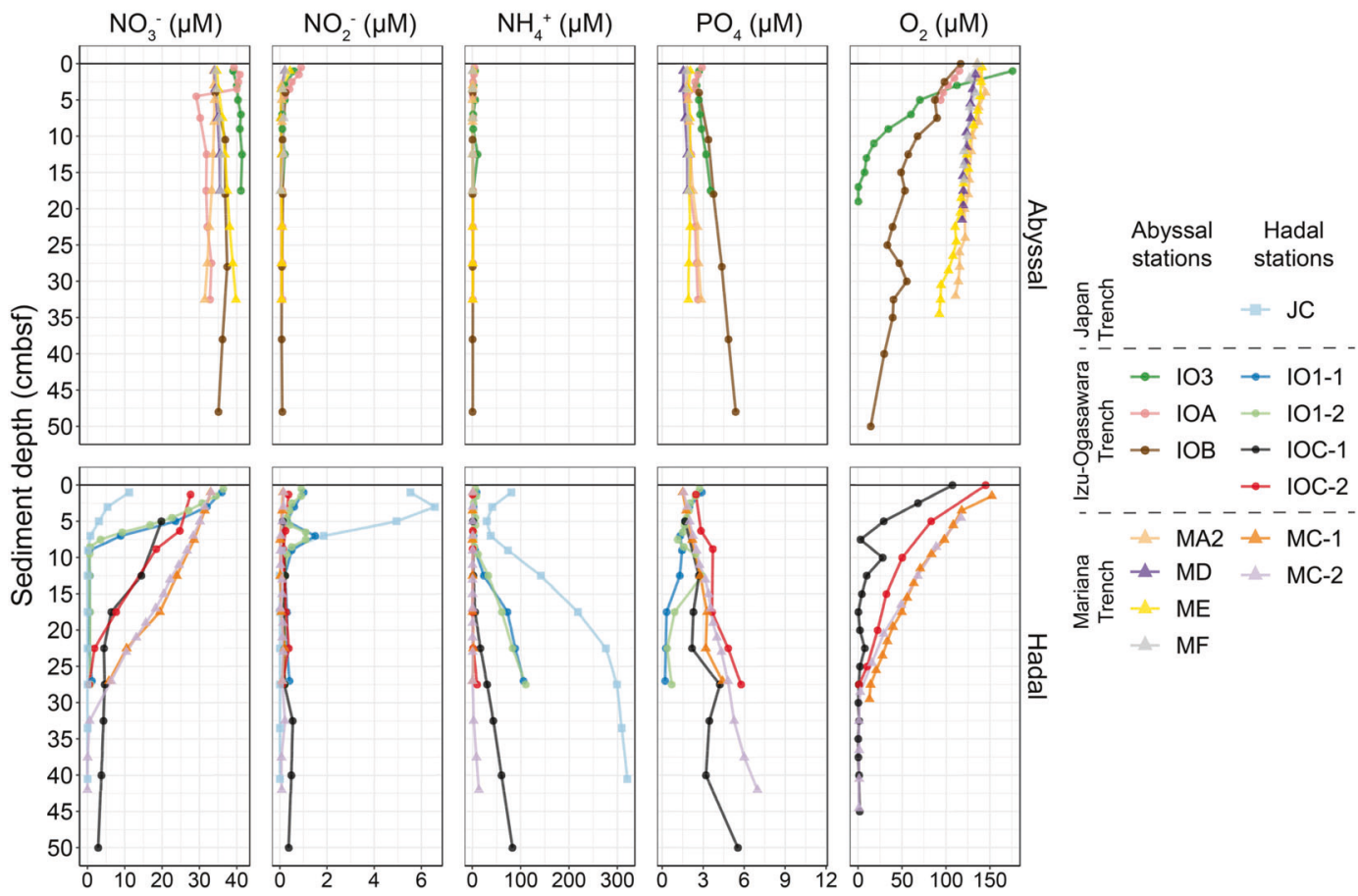

Fig. 2 Porewater chemistry of the surface sediments. Data down to $50 \mathrm{cmbsf}$ are presented in this figure and entire sediment data are presented in Fig. S3.

Trenches. In contrast, no apparent depletion of $\mathrm{NO}_{3}{ }^{-}(>27$ $\mu \mathrm{M})$ and lower $\mathrm{NH}_{4}^{+}$concentrations $(<11 \mu \mathrm{M})$ were observed throughout the sediment depths in all abyssal stations from the Izu-Ogasawara and Mariana Trench regions, which also exhibited low TOC concentrations. Notably, $\mathrm{NO}_{3}^{-}$profiles showed large variations among hadal sediments compared with abyssal sediments. Among the $\mathrm{NO}_{2}^{-}$profiles, clear subsurface peaks up to $6.6 \mu \mathrm{M}$ were found in only three sediment cores $(3,7$, and $7 \mathrm{cmbsf}$ of cores from JC, IO1-1, and IO1-2, respectively). $\mathrm{PO}_{4}$ concentrations generally increased with sediment depth, except for stations IO1-1 and IO1-2. These profiles of dissolved oxygen and nitrogen compounds are concordant with previous studies $[4,51]$. The profiles suggested that microbial nitrate respiration was relatively modest in abyssal sediments down to $50 \mathrm{cmbsf}$, whereas the respiration was active in hadal sediments above $30 \mathrm{cmbsf}$, probably reflecting higher concentrations of fresh OM. Interestingly, the increase rate of $\mathrm{NH}_{4}{ }^{+}$in hadal sediments along with sediment depth were gradually changed along with latitude of the sites (i.e., higher increasing rates at the northern site (JC) while lower in southern sites (MC-1 and MC-2)), suggestive of variance among stations in microbial populations and functions involved in nitrogen cycles.

\section{Microbial abundances}

The direct cell counting and qPCR technique showed similar trends in microbial abundance (Figs. 3 and S4).
Cell abundances by cell counting ranged from $4.2 \times 10^{5}$ to $9.6 \times 10^{7}$ cells $/ \mathrm{mL}$ sediment, with a general decrease with sediment depth, while scattered profiles were found in the hadal sites of the Japan and Izu-Ogasawara Trenches (Figs. 3a and S4a). The cell densities were similar to or even higher than those reported in other works $[4,52]$. Cell abundances in the hadal stations were generally higher than those in the adjacent abyssal stations. When comparing maximum cell abundances between cores, the largest and smallest cell abundances in hadal sites were found in the Japan and Mariana Trenches, respectively; for abyssal sites, abundance at the Izu-Ogasawara Trench was larger than that of the Mariana Trench. For qPCR analysis, the copy numbers of prokaryotic and archaeal SSU rRNA gene in each station ranged from $3.4 \times 10^{5}$ to $3.0 \times 10^{9}$ and $9.9 \times 10^{4}$ to $5.7 \times 10^{8}$ copies $/ \mathrm{mL}$ sediment, respectively (Figs. $3 \mathrm{~b}$ and $\mathrm{S} 4 \mathrm{~b}$ ). In addition, in the Mariana Trench region only, copy numbers from the shallow abyssal sediments were higher than those from the hadal sediments. The SSU rRNA gene copy numbers were 2-197-fold higher than the cell abundances by direct counting method, likely resulting from biases associated with direct cell counting (e.g., staining) [28] and molecular analyses (e.g., primers, probes, extracellular DNA, and/or SSU rRNA gene copy numbers on prokaryotic genomes [53, 54]. However, cell abundance and SSU rRNA gene copy number was significantly correlated (Fig. S5). Interestingly, the ratio of archaea to prokaryotes rapidly decreased at approximately under $20 \mathrm{cmbsf}$ of the 


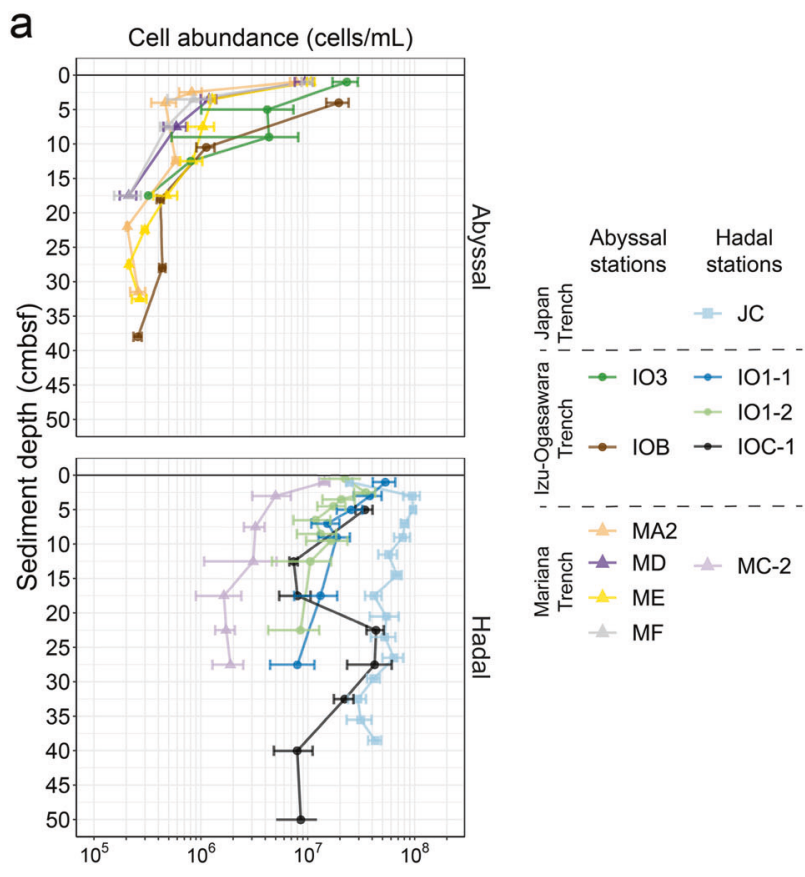

b
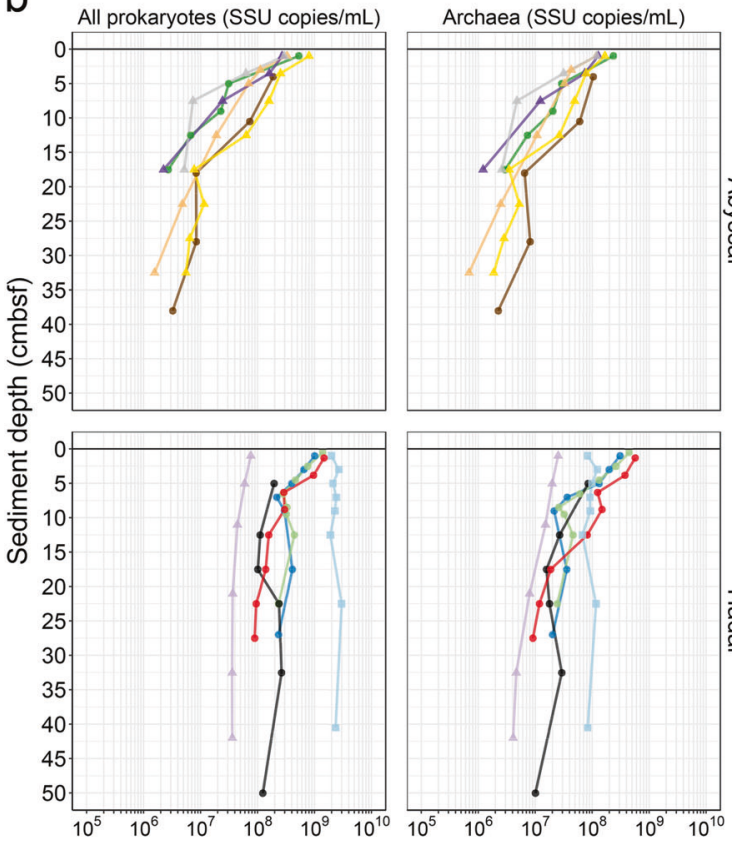

\section{C}

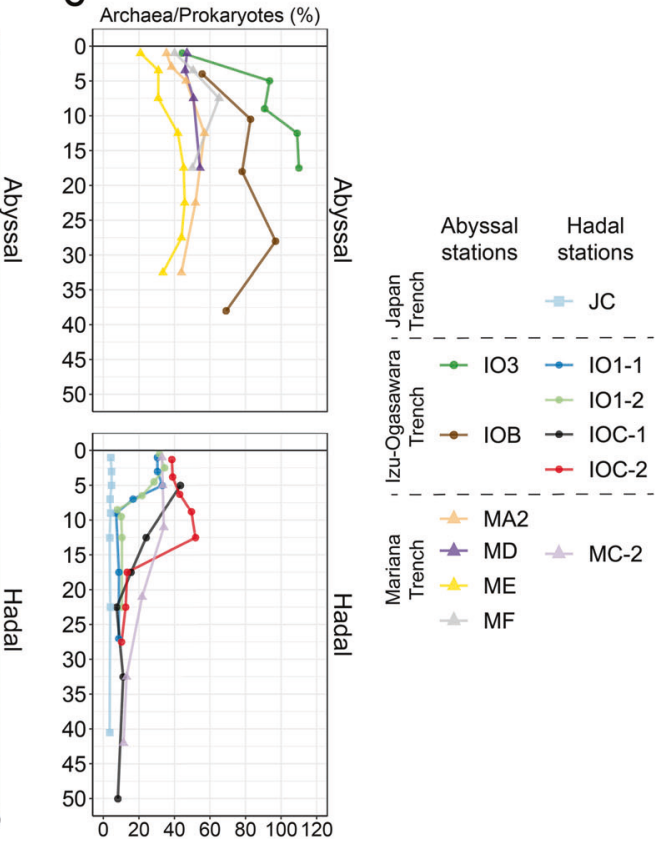

Fig. 3 The abundance of microbes and ratios of archaea. Abundances were measured using (a) cell counting and (b) qPCR techniques. The $X$-axis represents cell counts and SSU rRNA gene copies per milliliter of sediment, respectively. The error bars represent standard deviation.

hadal cores, while higher values were observed through the vertical profile in abyssal cores (Figs. 3c and S4c), which may be explained by lower nutrient availability in abyssal than hadal sites. Overall, these trends were consistent with previous studies [4, 52, 55, 56], supporting more vigorous microbial activity in hadal trench bottom sediments, especially in the subsurface under $5 \mathrm{cmbsf}$. (c) Ratios of archaea/prokaryotes were calculated using qPCR data. Data from layers ranging between 0 and $50 \mathrm{cmbsf}$ are presented in this figure, and full data are shown in Fig. S4.

\section{OTU-level compositions of microbial communities in sediment samples}

Based on the geochemical profiles in sediments, especially dissolved oxygen and nitrate concentrations, we selected four to ten layers from each sediment core for SSU rRNA gene tag sequencing. A total of $8,286,508$ high-quality SSU 

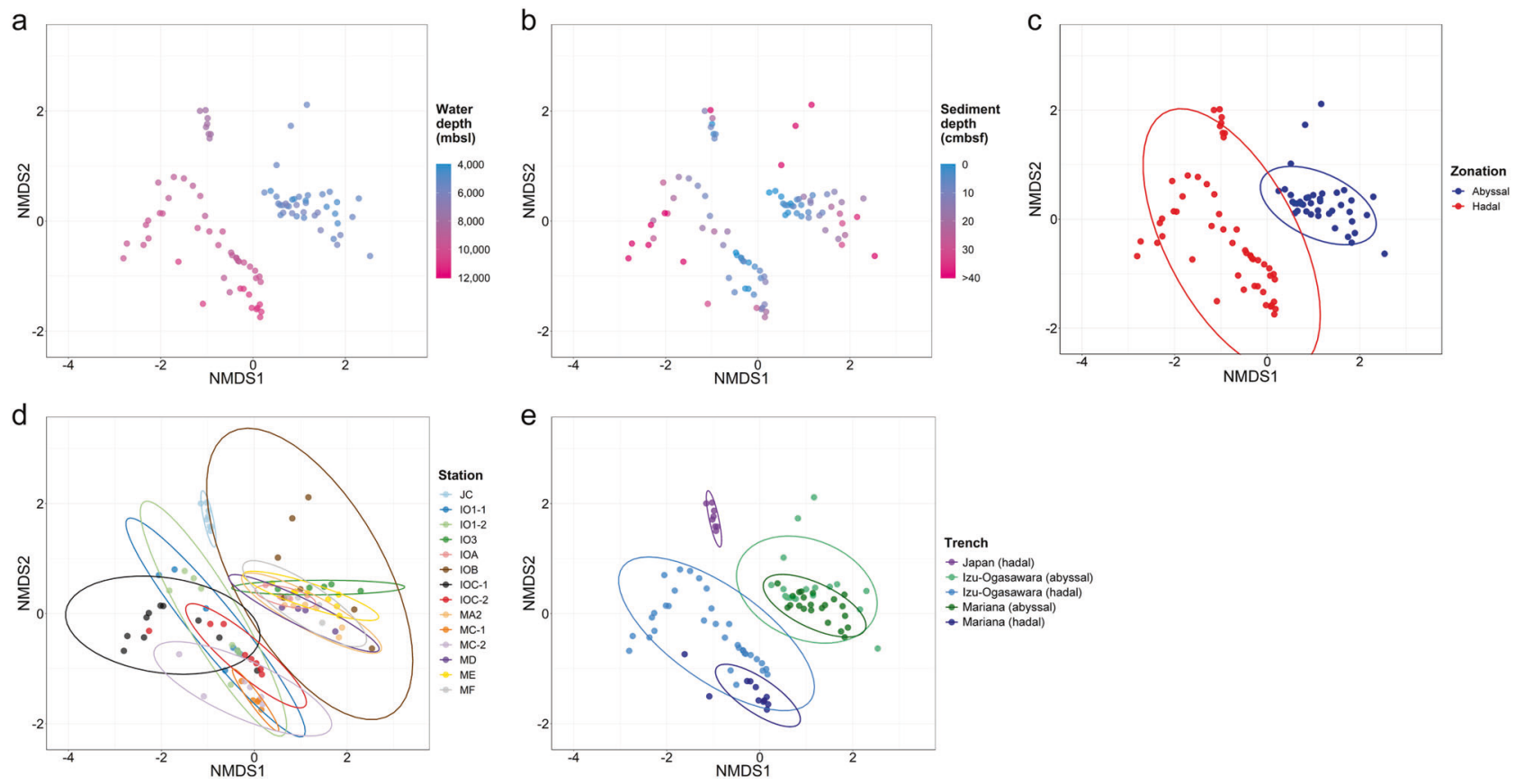

Fig. 4 Nonmetric multidimensional scaling (NMDS) plots for OTU compositions. The distance matrix was calculated based on the Bray-Curtis dissimilarity. The stress value of the final configuration was $18.2 \%$. The sediment samples were colored depending on (a)

water depth, (b) sediment depth, (c) zonation, (d) sampling station, and (d) trench and geomorphology. c-e Ellipsoids represent a 95\% confidence interval surrounding each group, and each sediment core, zonation, and geography are coded by color.

rRNA gene sequences with $414 \mathrm{bp}$ average length were obtained from the 92 sediment subsamples. The sequences comprised of 80,478 OTUs with 1587-13,181 (5478 average) OTUs per sample (Table S1). A number of OTU per sample were similar to or even higher than those reported in previous studies [21, 57]. Based on rarefaction curves, the obtained OTUs in each sediment sample well represented their microbial communities (Fig. S6).

To investigate compositional similarity between samples, we performed OTU-based NMDS analysis. OTU compositions were related to water depth (Fig. 4a) and generally similar along with sediment cores at each station (Fig. 4b). The OTU compositions were significantly differed between the abyssal and hadal sediments $(A=0.11, p<0.001$, MRPP) (Fig. 4c) and structured along the stations $(A=$ $0.31, p<0.001$ ) (Fig. 4d). Significant associations were also observed with each of the pair of trench and zonation. $(A=$ $0.21, p<0.001$ ) (Fig. 4e). Unexpectedly, the compositions in the abyssal sediments from the Izu-Ogasawara and Mariana Trench regions largely overlapped. The separation among the hadal sediments related with the different depression trends in porewater nitrate, TOC, and TN concentrations, but little with porewater oxygen concentration and cell abundance (Fig. S7).

Vertical profiles of community diversity in the hadal sediment cores were distinct from those of the abyssal cores (Fig. S8). The Shannon, Simpson, and Chao1 index values of all abyssal cores gradually decreased with sediment depth, while those in hadal samples fluctuated. Overall, the Shannon and Chao index values in the upper most layers at the abyssal stations were higher than those at the hadal stations. In hadal cores, index values were decreased at $\sim 5-20 \mathrm{cmbsf}$ and retained or increased below these layers. In all hadal cores from the Izu-Ogasawara Trench, the Shannon index plot showed clear peaks at 8-25 cmbsf and the values were higher than those of the most surface layers. Conversely, in hadal cores from the Mariana Trench, the index values were slightly increased in deep sediment sections ( $>10 \mathrm{cmbs})$, indicating that peaks were possibly located in layers deeper than $30 \mathrm{cmbsf}$. Interestingly, the diversity was decreased at layers close to those where depletion of oxygen and nitrate occurred (Fig. 2). These trends were concordant with the scattered microbial cell abundances observed in most of the hadal sediments in contrast to the abyssal sediments (Fig. 3). However, those trends were opposed to the general trends that prokaryotic growth and bioactivity are restricted according to sediment depth in energy-limited subseafloor sediments [48, 58, 59]. Thus, those trends of microbial diversity and cell abundance should be a unique feature of hadal subsurface biosphere. In the cases of gut and freshwater environments, it has been discussed that the supply of fresh nutrient resources generally correlate with microbial biomass and diversity $[60,61]$. According to the proposed theory, the feature of the hadal subsurface biosphere also could be explained by nutrient supply (i.e., the deposition of relatively fresh 


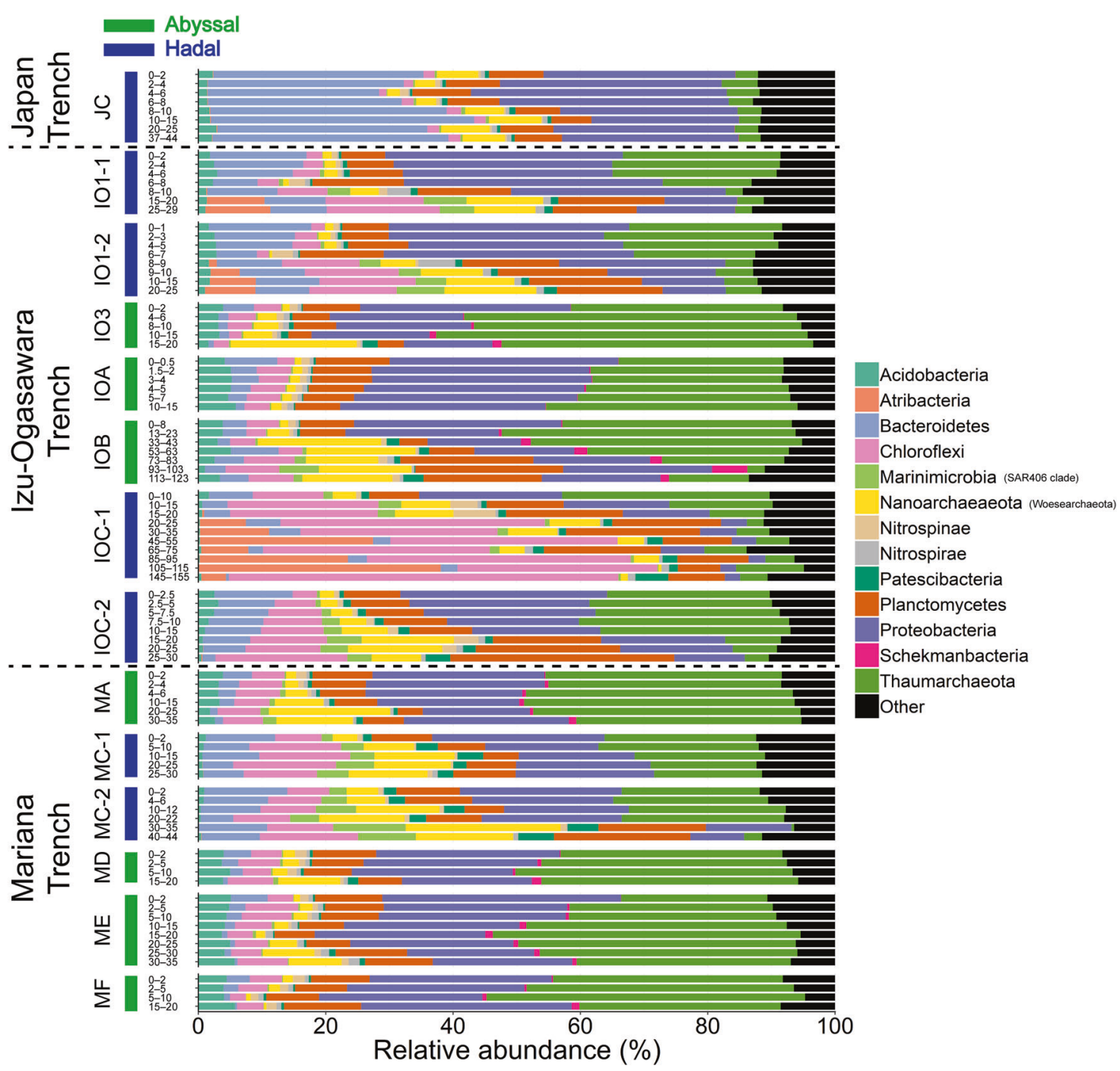

Fig. 5 Relative abundances of sequences at the phylum level. Groups with $<5 \%$ abundance were summarized as "Other." Sediment samples retrieved from deep sediment layers $(>50 \mathrm{cmbsf})$ are indicated by surrounding black rectangles.

organic compounds with high sedimentation rate as discussed above). Besides, recent deposition of sediments via landslide could be other potential source of microbial cells that lead to varying diversity with sediment depth.

\section{Taxonomic composition of microbial communities in sediment samples}

Among the retrieved OTUs, 76,881 (99.7\%) were taxonomically assigned to eleven Bacterial and two Archaeal phyla. Only 153 OTUs were assigned to Eukarya and the remaining 243 OTUs were taxonomically unassigned. The top three and ten most abundant phyla accounted for $>58 \%$ and $>88 \%$, respectively, of the sequence pool of all sediment samples. The most abundant OTU in the sequencing pool belonged to Thaumarchaeota, which represent seven of the top ten OTUs (Fig. S9 and Supplementary Data 1).

Overall, Thaumarchaeota (average 23.8\%) was the most abundant phylum, followed by Proteobacteria (23.7\%), Planctomycetes (10.6\%), Chloroflexi (9.6\%), Bacteroidetes (8.0\%), Nanoarchaeaeota (6.2\%), Acidobacteria (2.5\%), Candidatus ( $\mathrm{Ca}$.) Atribacteria (1.7\%), and $\mathrm{Ca}$. Marinimicrobia (1.7\%) (Fig. 5). Within sequencing reads assigned to Nanoarchaeaeota, $99.6 \%$ were assigned to class Woesearchaeia, currently proposed as novel phylum $\mathrm{Ca}$. Woesearchaeota. Thus, we assigned Nanoarchaeaeota as Woesearchaeota in this study. Within Proteobacteria, Gammaproteobacteria (10.3\%) is the most abundant class, followed by Alphaproteobacteria (8.4\%) and Deltaproteobacteria (5.1\%) (Fig. S10). In general, the dominant phyla were similar to those of previous studies of abyssal and 
hadal sediments [20, 21, 52, 57, 62-64]. The most abundant OTU within Eukarya belonged to Alveolata (41.5\%), followed by Stramenopiles (21.0\%), Nucletmycea (19.4\%), Holozoa (11.7\%), and Rhizaria (2.2\%).

Although dominant phyla were shared among subsamples within each of the sediment cores, their relative abundance gradually changed with sediment depth (Fig. 5). The relative abundances of Chloroflexi, Woesearchaeota, and Marinimicrobia generally increased in deeper sections (e.g., $>8 \mathrm{cmbsf}$ in IO1-2 and $>2.5 \mathrm{cmbsf}$ in IOC-2) along with the gradual decreases in oxygen and nitrate concentrations (Fig. 2). Conversely, Proteobacteria and Thaumarchaeota dominated in shallower sections (e.g., 0-7 cmbsf in IO1-2 and 0-22 cmbsf in MC-2). These trends are similar to previous studies [20, 21, 52, 57, 62, 63] and likely depend on the concentrations of dissolved oxygen and nitrate in sediments. Supporting this, correlation analysis between taxa and geochemistry showed that the abundances of Proteobacteria and Thaumarchaeota were significantly positively correlated with oxygen and nitrate concentrations, respectively (Fig. S11 and Supplementary Data 2). Woesearchaeota has been detected from diverse benthic and anaerobic environments [54,65-68] and harbors genomic capability for fermentation-based metabolism [69]; hence, they may contribute to anaerobic carbon and hydrogen cycles in the deep seafloor sediments.

We also observed some notable differences in prokaryotic communities likely associated with geographical location. Distinct community compositions were observed in station JC; Bacteroidetes dominated the communities (average 33.7\%), while Thaumarchaeota was relatively scarce $(4.1 \%)$. Within the Bacteroidetes, Flavobacteriaceae (belonging to class Flavobacteriia) is the most abundant family. The Flavobacterial OTUs abundant in station JC showed low similarity (88.0-91.4\%) against Flavobacteriaceae sp. PRS1, whose genome was reconstructed from the Maria Trench water sample via single cell technique [56]. Because members of Flavobacteriia were reported to be abundant in eutrophic oceans [70], our results likely reflect eutrophic productivity in the Japan Trench. The predominance of phyla Atribacteria was found only in deeper sections of IO1-1 (15-29 cmbsf), IO1-2 (8-25 cmbsf), and IOC-1 (20-155 cmbsf) hadal stations at the IzuOgasawara Trench. Atribacteria is a common lineage in organic rich anaerobic sediments and probably grow with fermentation [71-73]. The higher abundances of Flavobacteriia and Atribacteria may represent a substantial deposition of degradable organic compounds into hadal sediments.

The substantial differences revealed in the taxonomic analysis may also be explained by the geomorphological variations among sampling stations. Marinimicrobia showed significant unevenness between cores, with higher abundances observed in hadal $(2.6 \%)$ verses abyssal sediments $(0.73 \%)$ ( $p<0.05, U$-test, Bonferroni correction). Marinimicrobia is known to be a dominant population in deep sea sediments and seawater, especially in oxygenminimum zones, and harbors genetic potential of diverse energy metabolic processes using sulfur and nitrogenous compounds as electron donor and acceptor [74-78]. In contrast, $\mathrm{Ca}$. Schekmanbacteria was detected in all abyssal samples (average $0.82 \%$ ), while there was significantly lower abundance $(0.007 \%)$ in hadal samples $(p<0.05, U$ test, Bonferroni correction). Although several draft genomes of the recently proposed phyla Schekmanbacteria were reconstructed by metagenomic approach [79], their biological and geochemical importance remains unclear.

The relative abundance of Thaumarchaeota showed drastic decrease in hadal stations below 6-15 and 20-30 cmbsf in core(s) from the Izu-Ogasawara (IO1-1, IO1-2, IOC-1, and IOC-2) and Mariana (MC-2) Trenches, respectively, where nitrate was consumed and ammonium emerged (Fig. 2). In contrast, low abundance of Thaumarchaeota was continuously observed in sediments from the Japan Trench (JC), where nitrate concentration was depleted through the sediment core (Fig. 2). This was concordant with qPCR analyses (Fig. 3c), as well as previous observations that Thaumarchaeota frequently dominated in aerobic sediment columns and radially decreased across the oxic-anoxic transition layer [63, 80]. The most predominant family of Thaumarchaeota in the sediments was Nitrosopumilaceae (92\%), which are known to be ammonia oxidizing archaea (AOA) [81-83], and thus may contribute markedly to nitrification processes in trench surface sediments. The co-existence of Thaumarchaeota and Marinimicrobia at relatively high abundance suggests the co-existence of nitrification and denitrification processes, respectively, as described previously [52, 84]. Although abundance of functional genes related with nitrification (e.g., amoA) was not analyzed in this study, we should note that abundance of the amoA gene decreased with sediment depth in trench bottom sediments from the Mariana and IzuOgasawara Trenches [52, 84].

\section{Co-occurrence network structure of OTUs}

Many prokaryotic lineages are known to establish consortia with specific prokaryotic members, who inhabit same environment and sometimes sharing similar ecological niches and biological interactions (e.g., sharing metabolic compounds via fixation and translocating process) [85]. Since co-occurrence patterns can be useful for revealing such concrete but mostly hidden relationships from complex community datasets, co-occurrence network analyses have been widely applied to various SSU rRNA tag sequencing datasets of marine and other environments [86- 


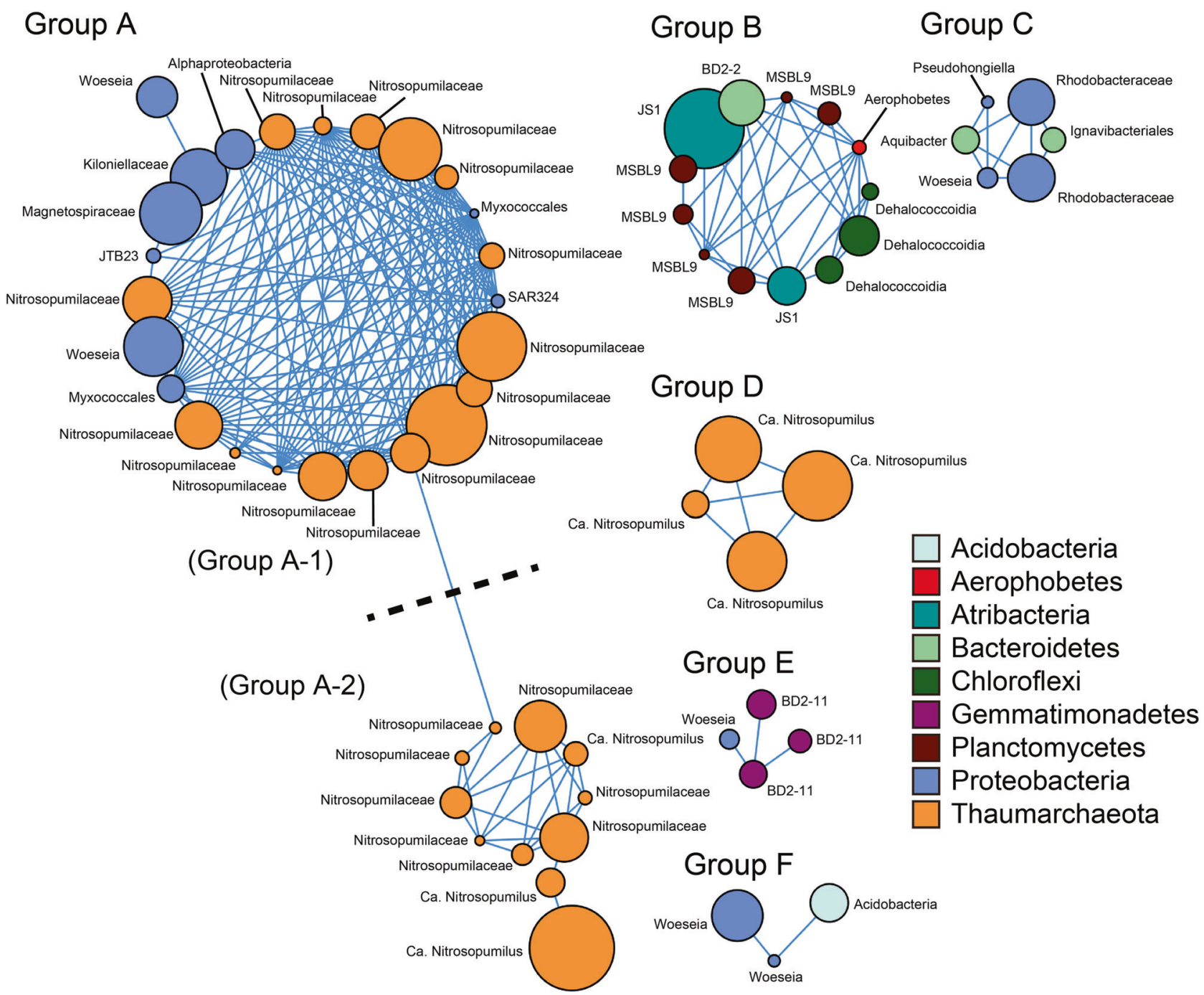

Fig. 6 Architecture of co-occurrence OTU networks. Nodes represent OTUs and edges (blue lines) represent statistically significant positive correlations of each OTU pair. The size of nodes represents relative abundance of OTUs in the data set. Nodes are colored by taxonomy at the phylum level.

Although OTUs of groups $\mathrm{C}$ and $\mathrm{F}$ were spread among the three trenches, those of groups $\mathrm{B}, \mathrm{D}$, and $\mathrm{E}$ were rare in cores from the Japan Trench.

Groups A and D were dominated by OTUs assigned to order Nitrosopumilales (Fig. S12). Nitrosopumilales are considered as aerobic nitrifying [81-83], and abundance of these OTUs were concordant with the high oxygen and nitrate concentrations in the sediments (Fig. 2). OTUs of group D belonged to one small clade (showing 95.6-96.1\% identity with $16 \mathrm{~S}$ rRNA gene of Nitrosopumilus maritimus SCM1 [DQ085097]) while those of group A were spread throughout the order. The niche separation of AOA subgroups is regulated by the availability of electron donors like ammonia [19, 90, 91]. Supporting this, the dominance of the group D clade (up to $78.1 \%$ in Thaumarchaeota in the hadal samples) is consistent with the enrichment of labile $\mathrm{OM}$ in the hadal sediments. Unfortunately, further subgroup 


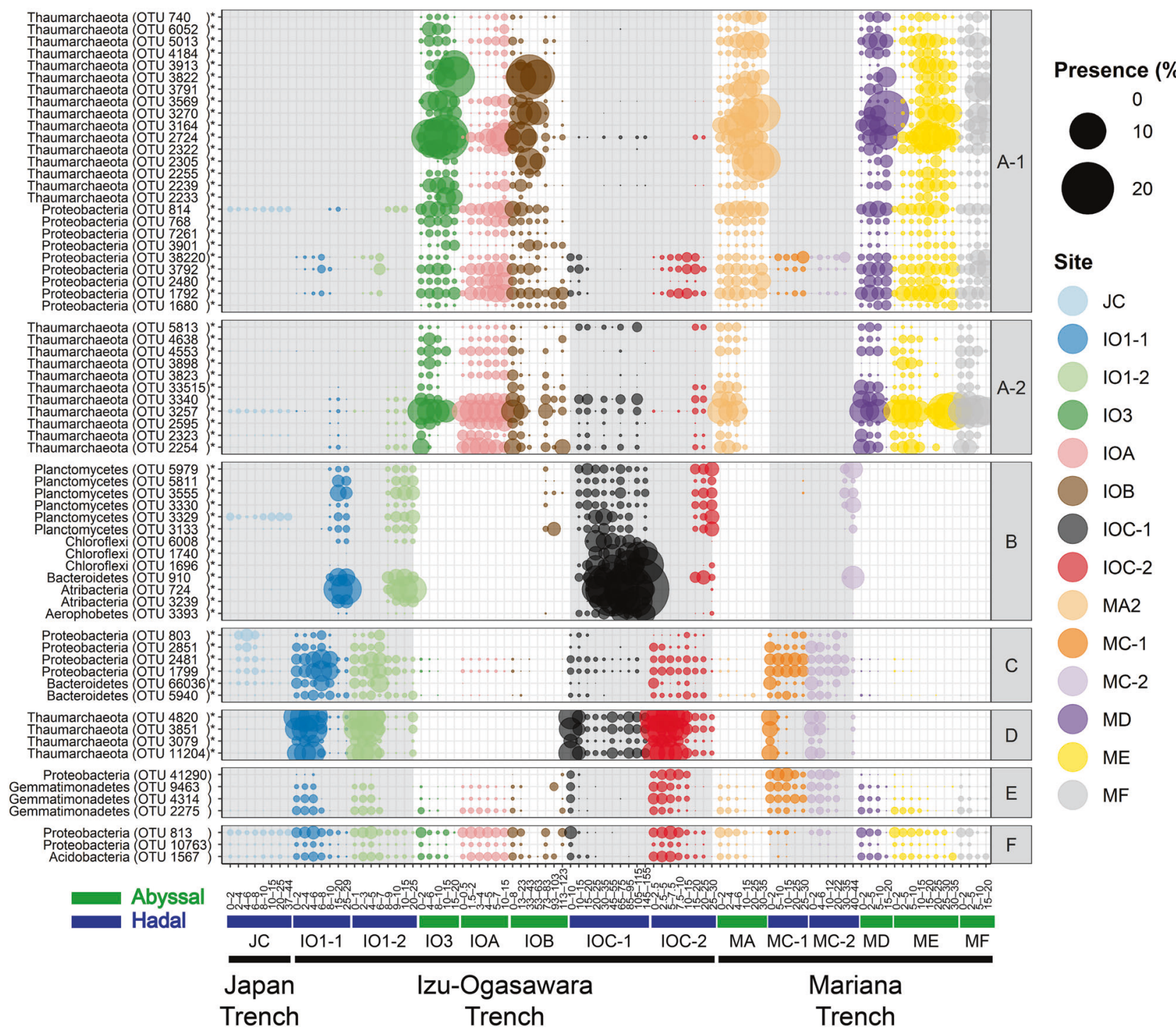

Fig. 7 Bubble plot showing comparative OTU profiles belonging to each co-occurrence network. Bubbles are colored by sampling station and bubble sizes correspond to relative abundances. The white and gray backgrounds represent abyssal and hadal sediment samples, respectively. A to $\mathrm{F}$ written in the right side represent co-occurrence network groups summarized in Fig. 6. OTUs with asterisks indicate statistical significance of localization in either the abyssal or the hadal samples $(p<0.05, U$-test, Bonferroni correction). assignment of Thaumarchaeota OTUs using short $16 \mathrm{~S}$ rRNA gene tag sequences were not technically feasible in contrast to the previously described amoA gene [43]. Although most proteobacterial OTUs in group A were assigned to lineages that currently less well-understood, two OTUs were assigned to genus Woeseia in Chromatiales; this genus likely possesses denitrification pathway-related genes [92], and may consume nitrates that provided by nitrifiers including Thaumarchaeota.

Intriguingly, group B consisted of 13 OTUs belonging to five phyla (Planctomycetes, Atribacteria, Chloroflexi, Bacteroidetes, and $\mathrm{Ca}$. Aerophobetes), and OTUs were abundant in the deeper sections where oxygen and nitrate were depleted (Fig. 2). All 13 OTUs showed highest sequence similarities with uncultured lineages, most of which were found in anaerobic environments with low oxygen concentrations. Atribacteria partake in fermentation metabolisms that produce acetate, hydrogen and carbon dioxide [71-73]. Similar to Atribacteria, recently defined bacterial phylum Aerophobetes were reported to harbor saccharolytic and fermentative metabolism capabilities [93]. All Planctomycetes OTUs were assigned to order MSBL9. Metagenome sequencing analyses identified genes encoding pyruvate formate-lyase from a member of MSBL9 [94], indicative of fermentation capabilities. All three Chloroflexi OTUs were assigned to class Dehalococcoidia, which is frequently detected from seafloor sediments and possesses genes related to hydrogen and sulfur compound oxidation 
with reductive dehalogenation of halogenated organic compounds [95-97]. Notably, MSBL9 and Dehalococcoidia possess potential of flavin secretion in marine sediments [98], implying that these lineages also contribute to maintaining extracellular metabolite pools in hadal sediments. The single Bacteroidetes OTU was affiliated with class BD2-2, which may interact with methanotrophic archaea and sulfate-reducing bacteria in methane seep sediments [99]. While knowledge of group B OTUs is still limited, they may cooperatively establish anaerobic metabolic networks; e.g. products of fermentation by Atribacteria, Aerophobetes, and MSBL9 are used as electron donors by BD2-2 and Dehalococcoidia OTUs, and then the fresh labile $\mathrm{OM}$ will be used as energy resources again in hadal sediments following necromass turnover recycling, as discussed previously [100].

Overall, the network structure analyses highlighted associations between prokaryotic consortia and geochemical conditions (geomorphological zonation and sediment depth). Part of these consortia may represent potential metabolic interactions with habitat transition, although further experimental validation should be required. In addition, the consortia structures were widespread among the trenches in the northwest Pacific Ocean. While three groups (B, C, and D) were selectively abundant in the hadal sediments, only one group (A) showed high preference in the abyssal sediments (Fig. 7).

\section{Factors impacting hadal subseafloor ecosystem}

Here, we conducted culture-independent molecular analyses of trans-trench prokaryotic communities in the abyssal plain and hadal trench bottom sediments collected from three different trench systems under different oceanographical settings to understand the general role of hadal environments on subsurface geochemical cycles and microbial ecosystems. Microbial cell abundance showed greater biomass in the hadal sediments verses abyssal sediments especially in deeper layers, which is consistent with previous studies $[4,52,55]$. Although we cannot exclude an impact of water pressure on benthic microbes [101], the clear relations between geochemistry and microbial community at the hadal sediments likely indicating more importance of factors related to geomorphology rather than merely water pressure. Overall, the microbial composition suggested that development of prokaryotic communities depends on ocean geomorphological zonation (i.e., abyssal vs. hadal), geographic regionality (i.e., productivity of overlying ocean surface), and factors associated with sediment depth. We also observed different vertical fluctuation of microbial community diversity between the hadal and abyssal sediments and identified potential prokaryotic consortia that spread among inter-trenches habitats and likely share energy-conserving metabolic processes in both abyssal and hadal sediments.

In general, deposition of $\mathrm{OM}$ and subsurface microbial cell abundance is related to productivity of the surface ocean and distance from continents or islands [48]. Indeed, in our abyssal sites, greater microbial cell abundance and oxygen consumption were observed in the Izu-Ogasawara compared with Mariana trench regions (Figs. 2 and 3). However, microbial compositions and some geochemical parameters (nitrate, TOC, and $\mathrm{TN}$ ) were unexpectedly similar between these two regions, indicating that the impact of surface productivity on subsurface microbial community is much smaller than expected in the abyssal plains under oligotrophic to ultraoligotrophic oceans. In the hadal sites, we found variations in geochemical parameters, cell abundances, and microbial compositions along with surface productivities. The differences between the abyssal and hadal sediments cannot only be explained by the vertical flux of sinking organic particles influenced by the ocean surface productivity. To explain the variations, we have two hypotheses. One of them is a presence of hadal currents that could supply intrinsic OM on hadal sites apart from those sinking directly from ocean surface. The other is a difference in sedimentation rates between hadal and abyssal sites that change the impact of ocean surface productivity on subsurface microbes.

Lateral transport along the trenches is one of the possible sources of OM in hadal trench bottom sediments apart from sinking OM. There are north- and south-ward currents along the trench axis at the Izu-Ogasawara and Japan Trenches, respectively [102, 103]. These currents may contribute to transportation of suspended particles with relatively high OM contents from the north to south. A part of the latitudinal gradients in TOC values among hadal sites (Fig. S1) could be explained either by this lateral OM supply, or benthic microbial populations that prefer subsurface ecosystems under eutrophic oceans represented by Atribacteria (Fig. 5). However, we could not find clear geochemical signatures supporting OM delivery along the trenches. Also such currents may contribute for microbial dispersal, growing up the importance to elucidate the water current in abyssal and hadal zones.

OM degradation process at the surface sediments may differ between hadal and abyssal sites due to differences in sedimentation rates, which are very high at hadal while low at abyssal sites. Extremely high sedimentation rates at hadal trench bottom, driven by landslides on trench slope via the funnel effect, cause the rapid deposition of labile OM into the subsurface [9, 55]. This burial prevents oxidative degradation of $\mathrm{OM}$ at surface sediments, allowing semilabile OM to be available to subsurface microbes. In contrast, abyssal plains generally have slower sedimentation rates. In our studied Izu-Ogasawara Trench sites, estimated 
sedimentation rates were 25 and $2.9 \mathrm{~cm}$ per 1000 years at the hadal (IOC-2) and abyssal (IOA) stations, respectively, based on bulk ${ }^{14} \mathrm{C}$-age analysis (Nomaki et al. unpublished data). The slower sedimentation rates at abyssal sites have allowed continuous oxic degradation of $\mathrm{OM}$ at surface sediments for over 1000 years, and labile OM are likely more diminished than those at hadal sites. Consequently, the differences in TOC concentrations $(0.11-0.55 \%)$ were small across the abyssal plains in our sites, while those at the hadal sites varied substantially (0.16-3.28\%) (Fig. S1). The variations in TOC concentration among the hadal trench bottom sediments subsequently influenced the dissolved oxygen and nitrate profiles through sediment depths (Fig. 2). Higher diversity of microbial communities among hadal than abyssal sediments (Fig. 4c) may reflect variations in TOC and porewater chemistries. Moreover, the differences in labile $\mathrm{OM}$ deposition may be reflected in the microbial cell abundance in the abyssal stations (Fig. 3) instead of microbial community structures.

Our findings provide new perspectives into hadal biospheres under different oceanographic regions, displaying contrasting properties to abyssal biospheres. We also identified novel insights into abyssal geochemistry and microbial communities whereby variations in surface productivity at abyssal sites are not profound in oligotrophic to ultraoligotrophic areas because the OM buried into subsurface sediments are extensively degraded before burial. However, we could not specify the factors controlling microbial ecosystems and biogeochemical cycles in this study. To further understand such controlling factors, investigation of microbiological processes in intra- and inter-cell scales and elucidation of biological mechanisms of trench systems that impact hadal biospheres are necessary. In addition, ecological functions and phylogenetic classifications of most predominant lineages in deep seafloor sediments remain largely unknown. Also, it should be noted that there is still difficulties in estimation of definitive phylogenetic and functional characters in genus or strain level based on the partial SSU rRNA gene sequencing reads. Moreover, although bacteria and archaea may account for a major part of ecosystems, viruses could facilitate biogeochemical cycles through biological interactions with prokaryotes in oligotrophic deep sea environment [100, 104-106]. Therefore, further taxonomic composition analyses, gene- and genome-centric approaches (e.g., metagenomics, metatranscriptomics, and metaepigenomics [107]), and integrative analyses with viruses (e.g., viromics) will provide further insights into microbial ecology and associated biogeochemical cycles.

Acknowledgements We would like to thank the captain, crew, and onboard scientists and technicians of the R/V Kairei (JAMSTEC) during KR11-11, KR12-19, KR14-01, and KR15-01 cruise, and the
R/V Yokosuka (JAMSTEC) during YK11-06 cruise. We are very grateful to HOV Shinkai 6500 and ROV ABISMO development and operation team. We thank Osamu Koide, Takaaki Kubota, Tomoko Makita, Masashi Tsuchiya, Kentaro Inoue, Mitsuhiro Yoshida, and Katsunori Yanagawa for sediment sampling, and Megumi Kuroiwa, Tomoko Makita, Shota Takino, Yasuhito Ito, Kazuki Shinoda, and Keisuke Koba for geochemical analyses. We also thank Shinsuke Kawagucci and Taichi Yokokawa for their helpful suggestions.

Funding This work was supported by the Japan Society for the Promotion of Science (Grant Numbers JP16K00534, JP17H01176, JP17H06455, JP18H05328, JP18H05368, JP18H06080, JP19H00988, JP19K04048, JP22540499, and JP24540504).

Author contributions SH conceived of and designed the study, performed the bioinformatics analyses, and wrote the manuscript. $\mathrm{MH}$ designed the experiments, and performed the sample collection, DNA extraction, qPCR analyses, and DNA sequencing. YM, AM, and MN designed and performed the geochemical experiments and analysis. MT performed the DNA extraction and qPCR analyses. J performed the DNA extraction, qPCR analyses, and cell counting. ER, RD, and CC performed the sample collection and cell counting. HM, TK, and ET contributed for the sample collection. KT supervised the project. $\mathrm{HN}$ designed the geochemical experiments and analysis and wrote the manuscript. TN conceived of and designed the study, wrote the manuscript, and supervised the project. All authors read and approved the final manuscript.

\section{Compliance with ethical standards}

Conflict of interest The authors declare that they have no conflict of interest.

Publisher's note Springer Nature remains neutral with regard to jurisdictional claims in published maps and institutional affiliations.

Open Access This article is licensed under a Creative Commons Attribution 4.0 International License, which permits use, sharing, adaptation, distribution and reproduction in any medium or format, as long as you give appropriate credit to the original author(s) and the source, provide a link to the Creative Commons license, and indicate if changes were made. The images or other third party material in this article are included in the article's Creative Commons license, unless indicated otherwise in a credit line to the material. If material is not included in the article's Creative Commons license and your intended use is not permitted by statutory regulation or exceeds the permitted use, you will need to obtain permission directly from the copyright holder. To view a copy of this license, visit http://creativecommons. org/licenses/by/4.0/.

\section{References}

1. Jamieson AJ, Fujii T, Mayor DJ, Solan M, Priede IG. Hadal trenches: the ecology of the deepest places on Earth. Trends Ecol Evol. 2010;25:190-7.

2. Liu R, Wang L, Wei Y, Fang J. The hadal biosphere: recent insights and new directions. Deep Sea Res Part II Top Stud Oceanogr. 2018;155:11-18.

3. Taira K, Yanagimoto D, Kitagawa S. Deep CTD casts in the challenger deep, Mariana Trench. J Oceanogr. 2005;61: 447-54.

4. Glud RN, Wenzhöfer F, Middelboe M, Oguri K, Turnewitsch R, Canfield DE, et al. High rates of microbial carbon turnover in 
sediments in the deepest oceanic trench on Earth. Nat Geosci. 2013;6:284

5. Kong X, Li S, Wang Y, Suo Y, Dai L, Géli L, et al. Causes of earthquake spatial distribution beneath the Izu-Bonin-Mariana Arc. J Asian Earth Sci. 2018;151:90-100.

6. Kawasaki I, Asai Y, Tamura Y. Space-time distribution of interplate moment release including slow earthquakes and the seismo-geodetic coupling in the Sanriku-oki region along the Japan trench. Tectonophysics. 2001;330: 267-83.

7. Kawagucci S, Yoshida YT, Noguchi T, Honda MC, Uchida H, Ishibashi $\mathrm{H}$, et al. Disturbance of deep-sea environments induced by the M9.0 Tohoku Earthquake. Sci Rep. 2012;2:270.

8. Kawagucci S, Makabe A, Kodama T, Matsui Y, Yoshikawa C, Ono E, et al. Hadal water biogeochemistry over the Izu-Ogasawara Trench observed with a full-depth CTD-CMS. Ocean Sci. 2018;14:575-88.

9. Oguri K, Kawamura K, Sakaguchi A, Toyofuku T, Kasaya T, Murayama M, et al. Hadal disturbance in the Japan Trench induced by the 2011 Tohoku-Oki Earthquake. Sci Rep. 2013; 3:1915.

10. Gamo T, Sshitashima K. Chemical characteristics of hadal waters in the Izu-Ogasawara Trench of the western Pacific Ocean. Proc Jpn Acad Ser B. 2018;94:45-55.

11. Bao R, Strasser M, McNichol AP, Haghipour N, McIntyre C, Wefer $\mathrm{G}$, et al. Tectonically-triggered sediment and carbon export to the hadal zone. Nat Commun. 2018;9:121.

12. Itou M, Matsumura I, Noriki S. A large flux of particulate matter in the deep Japan Trench observed just after the 1994 SanrikuOki earthquake. Deep Sea Res Part I Oceanogr Res Pap. 2000;47:1987-98.

13. Danovaro R, Della Croce N, Dell'Anno A, Pusceddu A. A depocenter of organic matter at $7800 \mathrm{~m}$ depth in the SE Pacific Ocean. Deep Sea Res Part I Oceanogr Res Pap. 2003; 50:1411-20.

14. Luo M, Gieskes J, Chen L, Shi X, Chen D. Provenances, distribution, and accumulation of organic matter in the southern Mariana Trench rim and slope: implication for carbon cycle and burial in hadal trenches. Mar Geol. 2017;386:98-106.

15. Jamieson AJ, Kilgallen NM, Rowden AA, Fujii T, Horton T, Lörz A-N, et al. Bait-attending fauna of the Kermadec Trench, SW Pacific Ocean: evidence for an ecotone across the abyssal-hadal transition zone. Deep Sea Res Part I Oceanogr Res Pap. 2011;58:49-62.

16. Kitahashi T, Kawamura K, Kojima S, Shimanaga M. Assemblages gradually change from bathyal to hadal depth: a case study on harpacticoid copepods around the Kuril Trench (northwest Pacific Ocean). Deep Sea Res Part I Oceanogr Res Pap. 2013;74:39-47.

17. Fujii T, Kilgallen NM, Rowden AA, Jamieson AJ. Deep-sea amphipod community structure across abyssal to hadal depths in the Peru-Chile and Kermadec trenches. Mar Ecol Prog Ser. 2013;492:125-38

18. Lacey NC, Rowden AA, Clark MR, Kilgallen NM, Linley T, Mayor DJ, et al. Community structure and diversity of scavenging amphipods from bathyal to hadal depths in three South Pacific Trenches. Deep Sea Res Part I Oceanogr Res Pap. 2016;111:121-37.

19. Nunoura T, Takaki Y, Hirai M, Shimamura S, Makabe A, Koide $\mathrm{O}$, et al. Hadal biosphere: insight into the microbial ecosystem in the deepest ocean on Earth. Proc Natl Acad Sci USA. 2015;112: E1230-E1236.

20. Peoples LM, Grammatopoulou E, Pombrol M, Xu X, Osuntokun $\mathrm{O}$, Blanton J, et al. Microbial community diversity within sediments from two geographically separated hadal trenches. Front Microbiol. 2019;10:347.
21. Cui G, Li J, Gao Z, Wang Y. Spatial variations of microbial communities in abyssal and hadal sediments across the Challenger Deep. PeerJ. 2019;7:e6961.

22. Ichino MC, Clark MR, Drazen JC, Jamieson A, Jones DOB, Martin AP, et al. The distribution of benthic biomass in hadal trenches: a modelling approach to investigate the effect of vertical and lateral organic matter transport to the seafloor. Deep Sea Res Part I Oceanogr Res Pap. 2015;100:21-33.

23. Jamieson AJ. A contemporary perspective on hadal science. Deep Sea Res Part II Top Stud Oceanogr. 2018;155:4-10.

24. Yoshida H, Ishibashi S, Watanabe Y, Inoue T, Tahara J, Sawa T, et al. The ABISMO mud and water sampling ROV for surveys at 11,000 m depth. Mar Technol Soc J. 2009;43:87-96.

25. Murashima T, Nakajoh H, Takami H, Yamauchi N, Miura A, Ishizuka T. $11,000 \mathrm{~m}$ class free fall mooring system. In: OCEANS 2009-EUROPE. 2019. IEEE, Bremen, Germany. 1-5 https://ieeexplore.ieee.org/document/5278342.

26. Nomaki H, Arai K, Suga H, Toyofuku T, Wakita M, Nunoura T, et al. Sedimentary organic matter contents and porewater chemistry at upper bathyal depths influenced by the 2011 off the Pacific coast of Tohoku Earthquake and tsunami. J Oceanogr. 2016;72:99-111.

27. Danovaro R, Molari M, Corinaldesi C, Dell'Anno A. Macroecological drivers of archaea and bacteria in benthic deep-sea ecosystems. Sci Adv. 2016;2:e1500961.

28. Morono $\mathrm{Y}$, Terada $\mathrm{T}$, Masui $\mathrm{N}$, Inagaki F. Discriminative detection and enumeration of microbial life in marine subsurface sediments. ISME J. 2009;3:503-11.

29. Takai K, Horikoshi K. Rapid detection and quantification of members of the archaeal community by quantitative PCR using fluorogenic probes. Appl Environ Microbiol. 2000;66:5066-72.

30. Nunoura T, Hirai M, Yoshida-Takashima $Y$, Nishizawa M, Kawagucci S, Yokokawa $\mathrm{T}$, et al. Distribution and niche separation of planktonic microbial communities in the water columns from the surface to the hadal waters of the Japan Trench under the Eutrophic Ocean. Front Microbiol. 2016;7:1261.

31. Nunoura T, Takaki Y, Kazama H, Hirai M, Ashi J, Imachi H, et al. Microbial diversity in deep-sea methane seep sediments presented by SSU rRNA gene tag sequencing. Microbes Environ. 2012;27:382-90.

32. Hirai M, Nishi S, Tsuda M, Sunamura M, Takaki Y, Nunoura T. Library construction from subnanogram DNA for pelagic sea water and deep-sea sediments. Microbes Environ. 2017;32:336-43.

33. Magoč T, Salzberg SL. FLASH: fast length adjustment of short reads to improve genome assemblies. Bioinformatics. 2011;27:2957-63.

34. Langmead B, Salzberg SL. Fast gapped-read alignment with Bowtie 2. Nat Methods. 2012;9:357-9.

35. Edgar RC, Haas BJ, Clemente JC, Quince C, Knight R. UCHIME improves sensitivity and speed of chimera detection. Bioinformatics. 2011;27:2194-2200.

36. Rognes T, Flouri T, Nichols B, Quince C, Mahé F. VSEARCH: a versatile open source tool for metagenomics. PeerJ. 2016;4: e2584.

37. Auer L, Mariadassou M, O’Donohue M, Klopp C, HernandezRaquet G. Analysis of large 16S rRNA Illumina data sets: Impact of singleton read filtering on microbial community description. Mol Ecol Resour. 2017;17:e122-e132.

38. Saary P, Forslund K, Bork P, Hildebrand F. RTK: efficient rarefaction analysis of large datasets. Bioinformatics. 2017;33: 2594-5.

39. Camacho C, Coulouris G, Avagyan V, Ma N, Papadopoulos J, Bealer K, et al. BLAST+: architecture and applications. BMC Bioinform. 2009;10:421.

40. Quast C, Pruesse E, Yilmaz P, Gerken J, Schweer T, Yarza P, et al. The SILVA ribosomal RNA gene database project: 
Improved data processing and web-based tools. Nucleic Acids Res. 2013;41:D590-D596.

41. Chen I-MA, Chu K, Palaniappan K, Pillay M, Ratner A, Huang $\mathrm{J}$, et al. IMG/M v.5.0: an integrated data management and comparative analysis system for microbial genomes and microbiomes. Nucleic Acids Res. 2018;47:D666-D677.

42. Price MN, Dehal PS, Arkin AP. FastTree 2-approximately maximum-likelihood trees for large alignments. PLoS ONE. 2010;5:e9490.

43. Alves RJE, Minh BQ, Urich T, von Haeseler A, Schleper C. Unifying the global phylogeny and environmental distribution of ammonia-oxidising archaea based on amoA genes. Nat Commun. 2018;9:1517.

44. Schleper C, Jurgens G, Jonuscheit M. Genomic studies of uncultivated archaea. Nat Rev Microbiol. 2005;3:479.

45. Manea E, Dell'Anno A, Rastelli E, Tangherlini M, Nunoura T, Nomaki $\mathrm{H}$, et al. Viral infections boost prokaryotic biomass production and organic $\mathrm{C}$ cycling in hadal trench sediments. Front Microbiol. 2019;10:1952.

46. Yoshikawa C, Makabe A, Matsui Y, Nunoura T, Ohkouchi N. Nitrate isotope distribution in the subarctic and subtropical North Pacific. Geochem Geophys Geosyst. 2018;19:2212-24.

47. Qiu B. Kuroshio and Oyashio Currents. Encyclopedia of Ocean Sciences. 2001. Elsevier, pp 358-69.

48. Kallmeyer J, Pockalny R, Adhikari RR, Smith DC, D'Hondt S. Global distribution of microbial abundance and biomass in subseafloor sediment. Proc Natl Acad Sci USA. 2012;109: 16213-6.

49. Gregg WW, Rousseaux CS. Decadal trends in global pelagic ocean chlorophyll: a new assessment integrating multiple satellites, in situ data, and models. J Geophys Res C Ocean. 2014;119:5921-33.

50. Froelich PN, Klinkhammer GP, Bender ML, Luedtke NA, Heath GR, Cullen D, et al. Early oxidation of organic matter in pelagic sediments of the eastern equatorial Atlantic: suboxic diagenesis. Geochim Cosmochim Acta. 1979;43:1075-90.

51. Leduc D, Rowden AA, Glud RN, Wenzhöfer F, Kitazato H, Clark MR. Comparison between infaunal communities of the deep floor and edge of the Tonga Trench: possible effects of differences in organic matter supply. Deep Sea Res Part I Oceanogr Res Pap. 2016;116:264-75.

52. Nunoura T, Nishizawa M, Hirai M, Shimamura S, Harnvoravongchai $\mathrm{P}$, Koide $\mathrm{O}$, et al. Microbial diversity in sediments from the bottom of the challenger deep, the Mariana Trench. Microbes Environ. 2018;33:186-94

53. Lloyd KG, May MK, Kevorkian RT, Steen AD. Meta-analysis of quantification methods shows that archaea and bacteria have similar abundances in the subseafloor. Appl Environ Microbiol. 2013;79:7790-9.

54. Corinaldesi C, Danovaro R, Dell'Anno A. Simultaneous recovery of extracellular and intracellular DNA suitable for molecular studies from marine sediments. Appl Environ Microbiol. 2005;71:46-50.

55. Wenzhöfer F, Oguri K, Middelboe M, Turnewitsch R, Toyofuku $\mathrm{T}$, Kitazato $\mathrm{H}$, et al. Benthic carbon mineralization in hadal trenches: assessment by in situ $\mathrm{O} 2$ microprofile measurements. Deep Sea Res Part I Oceanogr Res Pap. 2016;116:276-86.

56. Peoples LM, Norenberg M, Price D, McGoldrick M, Novotny $\mathrm{M}$, Bochdansky A, et al. A full-ocean-depth rated modular lander and pressure-retaining sampler capable of collecting hadalendemic microbes under in situ conditions. Deep Sea Res Part I Oceanogr Res Pap. 2019;143:50-57.

57. Peoples LM, Donaldson S, Osuntokun O, Xia Q, Nelson A, Blanton $\mathrm{J}$, et al. Vertically distinct microbial communities in the mariana and kermadec trenches. PLoS ONE. 2018;13: e0195102.
58. Starnawski P, Bataillon T, Ettema TJG, Jochum LM, Schreiber L, Chen X, et al. Microbial community assembly and evolution in subseafloor sediment. Proc Natl Acad Sci USA. 2017;114:2940-5.

59. Walsh EA, Kirkpatrick JB, Rutherford SD, Smith DC, Sogin M, D'Hondt S. Bacterial diversity and community composition from seasurface to subseafloor. ISME J. 2016;10:979-89.

60. Pereira FC, Berry D. Microbial nutrient niches in the gut. Environ Microbiol. 2017;19:1366-78.

61. Logue JB, Langenheder S, Andersson AF, Bertilsson S, Drakare S, Lanzén A, et al. Freshwater bacterioplankton richness in oligotrophic lakes depends on nutrient availability rather than on species-area relationships. ISME J. 2011;6:1127.

62. Schauer R, Bienhold C, Ramette A, Harder J. Bacterial diversity and biogeography in deep-sea surface sediments of the South Atlantic Ocean. ISME J. 2010;4:159-70.

63. Durbin AM, Teske A. Microbial diversity and stratification of South Pacific abyssal marine sediments. Environ Microbiol. 2011;13:3219-34.

64. Tarn J, Peoples LM, Hardy K, Cameron J, Bartlett DH. Identification of free-living and particle-associated microbial communities present in hadal regions of the Mariana Trench. Front Microbiol. 2016;7:665.

65. Takai K, Horikoshi K. Genetic diversity of archaea in deep-sea hydrothermal vent environments. Genetics. 1999;152:1285-97.

66. Nercessian O, Reysenbach AL, Prieur D, Jeanthon C. Archaeal diversity associated with in situ samplers deployed on hydrothermal vents on the East Pacific Rise. Environ Microbiol. 2003;5:492-502.

67. Lindh MV, Maillot BM, Shulse CN, Gooday AJ, Amon DJ, Smith CR, et al. From the surface to the deep-sea: Bacterial distributions across polymetallic nodule fields in the clarionclipperton zone of the Pacific Ocean. Front Microbiol. 2017:8:1696.

68. Nunoura T, Oida H, Nakaseama M, Kosaka A, Ohkubo SB, Kikuchi T, et al. Archaeal diversity and distribution along thermal and geochemical gradients in hydrothermal sediments at the yonaguni knoll IV hydrothermal field in the Southern Okinawa Trough. Appl Environ Microbiol. 2010;76:1198-211.

69. Castelle CJ, Wrighton KC, Thomas BC, Hug LA, Brown CT, Wilkins MJ, et al. Genomic expansion of domain Archaea highlights roles for organisms from new phyla in anaerobic carbon cycling. Curr Biol. 2015;25:690-701.

70. Gómez-Pereira PR, Fuchs BM, Alonso C, Oliver MJ, van Beusekom JEE, Amann R. Distinct flavobacterial communities in contrasting water masses of the North Atlantic Ocean. ISME J. 2010;4:472.

71. Carr SA, Orcutt BN, Mandernack KW, Spear JR. Abundant Atribacteria in deep marine sediment from the Adélie Basin, Antarctica. Front Microbiol. 2015;6:872.

72. Nobu MK, Dodsworth JA, Murugapiran SK, Rinke C, Gies EA, Webster G, et al. Phylogeny and physiology of candidate phylum 'Atribacteria' (OP9/JS1) inferred from cultivation-independent genomics. ISME J. 2016;10:273-86.

73. Lee YM, Hwang K, Lee JIl, Kim M, Hwang CY, Noh HJ, et al. Genomic insight into the predominance of candidate phylum Atribacteria JS1 lineage in marine sediments. Front Microbiol. 2018;9:2909.

74. Hawley AK, Nobu MK, Wright JJ, Durno WE, Morgan-Lang C, Sage B, et al. Diverse Marinimicrobia bacteria may mediate coupled biogeochemical cycles along eco-thermodynamic gradients. Nat Commun. 2017;8:1507.

75. Bertagnolli AD, Padilla CC, Glass JB, Thamdrup B, Stewart FJ. Metabolic potential and in situ activity of marine Marinimicrobia bacteria in an anoxic water column. Environ Microbiol. 2017;19:4392-416. 
76. Allers E, Wright JJ, Konwar KM, Howes CG, Beneze E, Hallam SJ, et al. Diversity and population structure of Marine Group A bacteria in the Northeast subarctic Pacific Ocean. ISME J. 2013;7:256-68.

77. Wright JJ, Mewis K, Hanson NW, Konwar KM, Maas KR, Hallam SJ. Genomic properties of Marine Group A bacteria indicate a role in the marine sulfur cycle. ISME J. 2014;8:455-68.

78. Tully BJ, Heidelberg JF. Potential mechanisms for microbial energy acquisition in oxic deep-sea sediments. Appl Environ Microbiol. 2016;82:4232-43.

79. Anantharaman K, Brown CT, Hug LA, Sharon I, Castelle CJ, Probst AJ, et al. Thousands of microbial genomes shed light on interconnected biogeochemical processes in an aquifer system. Nat Commun. 2016;7:13219.

80. Durbin AM, Teske A. Sediment-associated microdiversity within the Marine Group I Crenarchaeota. Environ Microbiol Rep. 2010;2:693-703.

81. Francis CA, Roberts KJ, Beman JM, Santoro AE, Oakley BB. Ubiquity and diversity of ammonia-oxidizing archaea in water columns and sediments of the ocean. Proc Natl Acad Sci USA. 2005;102:14683-8.

82. Pester M, Schleper C, Wagner M. The Thaumarchaeota: an emerging view of their phylogeny and ecophysiology. Curr Opin Microbiol. 2011;14:300-6.

83. Wuchter C, Abbas B, Coolen MJL, Herfort L, van Bleijswijk J, Timmers $\mathrm{P}$, et al. Archaeal nitrification in the ocean. Proc Natl Acad Sci USA. 2006;103:12317-22.

84. Nunoura T, Nishizawa M, Kikuchi T, Tsubouchi T, Hirai M, Koide $\mathrm{O}$, et al. Molecular biological and isotopic biogeochemical prognoses of the nitrification-driven dynamic microbial nitrogen cycle in hadopelagic sediments. Environ Microbiol. 2013;15: 3087-107.

85. Chaffron S, Rehrauer H, Pernthaler J, Mering C. A global network of coexisting microbes from environmental and wholegenome sequence data. Genome Res. 2010;2010:947-59.

86. Lima-Mendez G, Faust K, Henry N, Decelle J, Colin S, Carcillo $\mathrm{F}$, et al. Determinants of community structure in the global plankton interactome. Science. 2015;348:1262073.

87. Milici M, Deng Z-L, Tomasch J, Decelle J, Wos-Oxley ML, Wang $\mathrm{H}$, et al. Co-occurrence analysis of microbial taxa in the Atlantic Ocean reveals high connectivity in the free-living bacterioplankton. Front Microbiol. 2016;7:649.

88. Barberán A, Bates ST, Casamayor EO, Fierer N. Using network analysis to explore co-occurrence patterns in soil microbial communities. ISME J. 2012;6:343-51.

89. Cardinale M, Grube M, Erlacher A, Quehenberger J, Berg G. Bacterial networks and co-occurrence relationships in the lettuce root microbiota. Environ Microbiol. 2015;17:239-52.

90. Martens-Habbena W, Berube PM, Urakawa H, de la Torre JR, Stahl DA. Ammonia oxidation kinetics determine niche separation of nitrifying Archaea and Bacteria. Nature. 2009;461:976.

91. Sintes E, Bergauer K, De Corte D, Yokokawa T, Herndl GJ. Archaeal amoA gene diversity points to distinct biogeography of ammonia-oxidizing Crenarchaeota in the ocean. Environ Microbiol. 2013;15:1647-58.

92. Mußmann M, Pjevac P, Krüger K, Dyksma S. Genomic repertoire of the Woeseiaceae/JTB255, cosmopolitan and abundant core members of microbial communities in marine sediments. ISME J. 2017;11:1276.

93. Dong X, Greening C, Rattray JE, Chakraborty A, Chuvochina M, Mayumi D, et al. Metabolic potential of uncultured bacteria and archaea associated with petroleum seepage in deep-sea sediments. Nat Commun. 2019;10:1816.

94. Robbins SJ, Evans PN, Parks DH, Golding SD, Tyson GW. Genome-centric analysis of microbial populations enriched by hydraulic fracture fluid additives in a coal bed methane production well. Front Microbiol. 2016;7:731.

95. Kaster AK, Mayer-Blackwell K, Pasarelli B, Spormann AM. Single cell genomic study of dehalococcoidetes species from deep-sea sediments of the peruvian margin. ISME J. 2014;8: 1831-42.

96. Futagami T, Morono Y, Terada T, Kaksonen AH, Inagaki F. Dehalogenation activities and distribution of reductive dehalogenase homologous genes in marine subsurface sediments. Appl Environ Microbiol. 2009;75:6905-9.

97. Wasmund K, Cooper M, Schreiber L, Lloyd KG, Baker BJ, Petersen DG, et al. Single-cell genome and group-specific dsrAB sequencing implicate marine members of the class Dehalococcoidia (phylum Chloroflexi) in sulfur cycling. mBio. 2016;7:e00266-16.

98. Monteverde DR, Sylvan JB, Suffridge C, Baronas JJ, Fichot E, Fuhrman J, et al. Distribution of extracellular flavins in a coastal marine basin and their relationship to redox gradients and microbial community members. Environ Sci Technol. 2018;52: $12265-74$

99. Trembath-Reichert E, Case DH, Orphan VJ. Characterization of microbial associations with methanotrophic archaea and sulfatereducing bacteria through statistical comparison of nested Magneto-FISH enrichments. PeerJ. 2016;4:e1913.

100. Orsi WD. Ecology and evolution of seafloor and subseafloor microbial communities. Nat Rev Microbiol. 2018;16:671-83.

101. Bartlett DH. Pressure effects on in vivo microbial processes. Biochim Biophys Acta. 2002;1595:367-81.

102. Fujio S, Yanagimoto D, Taira K. Deep current structure above the Izu-Ogasawara Trench. J Geophys Res Ocean. 2000; 105:6377-86.

103. Mitsuzawa K, Holloway G. Characteristics of deep currents along trenches in the northwest Pacific. J Geophys Res Ocean. 1998;103:13085-92.

104. Dell'Anno A, Corinaldesi C, Danovaro R. Virus decomposition provides an important contribution to benthic deep-sea ecosystem functioning. Proc Natl Acad Sci USA. 2015;112: E2014-E2019.

105. Danovaro R, Dell'Anno A, Corinaldesi C, Rastelli E, Cavicchioli R, Krupovic M, et al. Virus-mediated archaeal hecatomb in the deep seafloor. Sci Adv. 2016;2:e1600492.

106. Worden AZ, Follows MJ, Giovannoni SJ, Wilken S, Zimmerman AE, Keeling PJ. Rethinking the marine carbon cycle: Factoring in the multifarious lifestyles of microbes. Science. 2015;347: 1257594.

107. Hiraoka S, Okazaki Y, Anda M, Toyoda A, Nakano S, Iwasaki W. Metaepigenomic analysis reveals the unexplored diversity of DNA methylation in an environmental prokaryotic community. Nat Commun. 2019;10:159. 